\title{
A Combined Experimental/Computational Study of the Mechanism of a Palladium-Catalyzed Bora-Negishi Reaction
}

Jesús Campos ${ }^{\mathrm{a}, \mathrm{b} *}$, Ainara Novac*, Eugene L. Kolychev ${ }^{\mathrm{a}}$, Simon Aldridge ${ }^{\mathrm{a} *}$

\begin{abstract}
Experimental and computational efforts are reported which illuminate the mechanism of a novel boron version of the widespread Negishi coupling reaction that offers a new protocol for the formation of aryl/acyl C-B bonds using a bulky boryl fragment. The role of nucleophilic borylzinc reagents in the reduction of the $\mathrm{Pd}(\mathrm{II})$ pre-catalysts to $\mathrm{Pd}(0)$ active species has been demonstrated. The non-innocent behavior of the $\mathrm{PPh}_{3}$ ligands of the $\left[\mathrm{Pd}\left(\mathrm{PPh}_{3}\right)_{2} \mathrm{Cl}_{2}\right]$ pre-catalyst under activation conditions has been probed both experimentally and computationally, revealing the formation of a trimetallic $\mathrm{Pd}$ species bearing bridging phosphide $\left(\mathrm{PPh}_{2}{ }^{-}\right)$ligands. Our studies also reveal the monoligated formulation of the $\mathrm{Pd}(0)$ active species, which led us to synthesize related $\left(\eta^{3}\right.$-indenyl)Pd-monophosphine catalysts which show improved catalytic performances under mild conditions. A complete mechanistic proposal to aid future catalyst developments is provided.
\end{abstract}

\section{Introduction}

Palladium-catalyzed cross-coupling reactions have revolu-tionized synthetic organic chemistry since first breaking onto the scene in the 1970s. ${ }^{1}$ Owing to their wide functional group tolerance, and systematic tunability by rational ligand design, these methods have been successfully transplanted from academic laboratories to industrial finechemical, pharma-ceutical and agrochemical production. ${ }^{2}$ The Suzuki-Miyaura coupling, in which a $\mathrm{C}-\mathrm{C}$ bond is formed using an organoboron reagent, is arguably the most widely applied metal-mediated crosscoupling transformation. Here, the choice of the boron-containing component is known to be critical for the outcome of the reaction, ${ }^{3}$ with boronic acid/esters being the most widely used class of reagent. ${ }^{4}$ These compounds in turn are typically prepared by the borylation of C-halogen or C-H bonds using diboron(4) esters of general formula $\mathrm{B}_{2}(\mathrm{OR})_{4} \cdot{ }^{1 \mathrm{~b}}$

Very recently, we developed an alternative strategy for the borylation of $\mathrm{C}-\mathrm{X}(\mathrm{X}=\mathrm{Br}, \mathrm{Cl})$ bonds using polar, formally anionic, borylzinc reagents, ${ }^{5}$ in the presence of simple and affordable palladium pre-catalysts (Scheme 1). ${ }^{6}$ In effect, this approach constitutes a novel boron version of the widelyapplied Negishi C-C coupling reaction. Importantly, our method has allowed us to develop the first efficient, systematic and catalytic route to acylboranes, ${ }^{7,89}$ a rare class of organoboron compound with high potential in synthetic organic chemistry. ${ }^{10}$

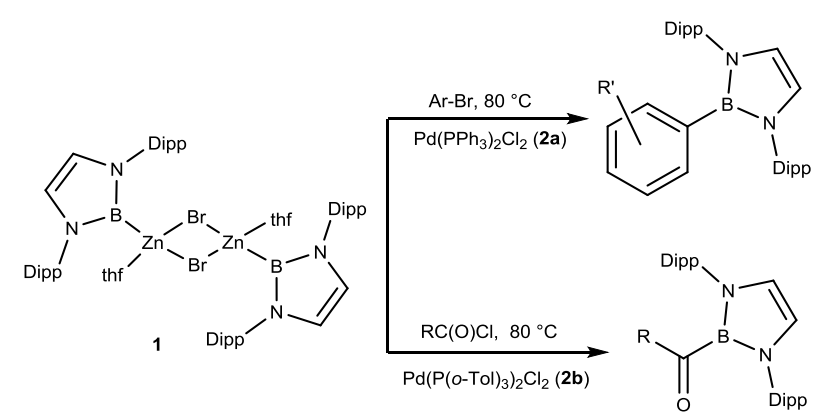

Scheme 1. Palladium-catalyzed borylation of aryl bromides and acyl chlorides using borylzinc reagent 1 (Dipp $=2,6$-diisopropylphenyl). ${ }^{6}$

Many palladium-catalyzed cross coupling reactions are believed to proceed through a common catalytic cycle involving oxidative addition of the organic substrate at a

[a] Prof. Simon Aldridge and Dr. Jesús Campos Inorganic Chemistry Laboratory, South Parks Road, Oxford, UK, OX1 3QR. *simon.aldridge@chem.ox.ac.uk; *jesus.campos@iiq.csic.es

[b] Instituto de Investigaciones Químicas (IIQ), Departamento de Química Inorgánica and Centro de Innovación en Química Avanzada (ORFEO-CINQA). Universidad de Sevilla and Consejo Superior de Investigaciones Científicas (CSIC). Avenida Américo Vespucio 49, 41092 Sevilla (Spain).

[c] Dr. Ainara Nova

Centre for Theoretical and Computational Chemistry (CTCC), Department of Chemistry, University of Oslo, P. O. Box 1033 Blindern, 0315 Oslo, Norway.

*ainara.nova@kjemi.uio.no

Details on the alternative one-step synthesis of borylzinc reagents, crystallographic information, NMR spectra and computational details and tables.

Supporting information for this article is given via a link at the end of the document. 
$\mathrm{Pd}(0)$ centre, followed by transmetalation of the coupling partner and reductive elimination of the organic product, with concomitant catalyst regeneration (Figure 1). ${ }^{1 a, c, d}$ The $\mathrm{Pd}(0)$ active species is usually generated via in situ reduction of a $\mathrm{Pd}$ (II) pre-catalyst by one of a number of potential routes. That said, it is apparent that the picture is often more complicated than this simple mechanistic model would imply, and subtle modifications to the reaction medium, for example, can lead to drastic changes in reactivity, ${ }^{11}$ particularly in processes involving highly polar zinc reagents. ${ }^{12}$ As a consequence, detailed studies have proved to be crucial in developing mechanistic understanding, which in turn can be applied to the rational design of new catalysts with enhanced performance, superior selectivity or broader applicability.

In the current contribution we present a joint experi-mental/computational effort to elucidate the mechanism of the novel bora-Negishi coupling which we believe may illuminate future catalyst developments. A key mechanistic aspect in most palladium-mediated organoboron reactions is the role of the added base: potentially, this is required to access a transient boron-centered nucleophile, ${ }^{13}$ although additional roles have also been suggested. ${ }^{14}$ One of the benefits of the bora-Negishi system is that it allows this issue (and associated mechanistic complexities derived from the presence of the base $)^{15}$ to be disregarded, since the intrinsic nucleophilicity of borylzinc reagents removes the need for external additives of this type. In addition, we report an alternative convenient one-step synthetic protocol to access airstable borylzinc reagents directly from a bromoborane, and thereby circumvent the need to use Yamashita's highly sensitive boryllithium complex (thf) $)_{2} \mathrm{Li}\left\{\mathrm{B}(\mathrm{NDippCH})_{2}\right\}^{16}$ as a precursor (see Experimental Section and Supporting Information for details). As such, this simple development significantly enhances the convenience of the bora-Negishi methodology in synthetic organic chemistry.

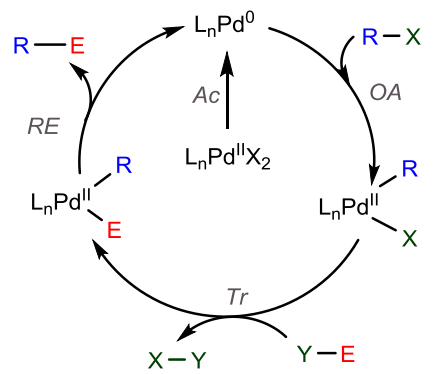

Figure 1. General catalytic cycle for palladium-catalyzed cross-coupling reactions $(A c=$ activation; $O A=0 x i d a t i v e$ addition; $\mathrm{Tr}=$ transmetalation; $\mathrm{RE}=$ reductive elimination).

\section{Results and Discussion}

\section{Catalyst pre-activation to generate $\mathrm{Pd}(0)$ species}

Although systems based on $\mathrm{Pd}(\mathrm{II}) / \mathrm{Pd}(\mathrm{IV})$ pairs have been reported, ${ }^{17}$ it is well known that $\mathrm{L}_{n} \mathrm{Pd}(0)$ species are the active catalysts in most palladium-mediated cross-coupling reactions. Palladium nanoparticles and other heterogeneous forms of palladium have shown outstanding catalytic properties. ${ }^{18}$ Nevertheless, according to poisoning experiments with $\mathrm{CS}_{2}, \mathrm{PPh}_{3}$ and $\mathrm{Hg}$ carried out during our preliminary investigation, ${ }^{19}$ such species are not the active catalyst in our system. ${ }^{6}$ Alternative radical pathways related to those reported by Marder ${ }^{20}$ for zinc-catalyzed borylation could also be ruled out based on the borylation of organic substrates specifically designed as radical probes. ${ }^{6}$ 
Active $L_{n} P d(0)$ species are typically generated via the in situ reduction of $\mathrm{Pd}(\mathrm{II})$ salts by the action of phosphines, ${ }^{21}$ amines,${ }^{22}$ hydride sources, ${ }^{23}$ other additives,${ }^{24}$ or even by electrochemical methods ${ }^{25}$ However, despite the extensive use of air and moisture stable $\left[\mathrm{Pd}_{(}\left(\mathrm{PAr}_{3}\right)_{2} \mathrm{X}_{2}\right]$ pre-catalysts in cross-coupling reactions, the pre-activation mechanisms by which the active species $L_{n} P d(0)$ are generated are not fully understood. ${ }^{26}$ In the bora-Negishi case, the strongly reducing nature of boryl derivatives of main group metals prompted us to first examine the ability of the borylzinc reagent 1 to give access to $\mathrm{Pd}(0)$-phosphine species, as well as the mechanism by which these may be formed. In these and subsequent investigations we have focused primarily on the pre-catalyst $\left[\mathrm{Pd}\left(\mathrm{PPh}_{3}\right)_{2} \mathrm{Cl}_{2}\right](2 \mathrm{a})$, owing to its superior performance and wider substrate applicability in the borylation of aryl bromides when compared to other Pd(II) sources. ${ }^{6}$

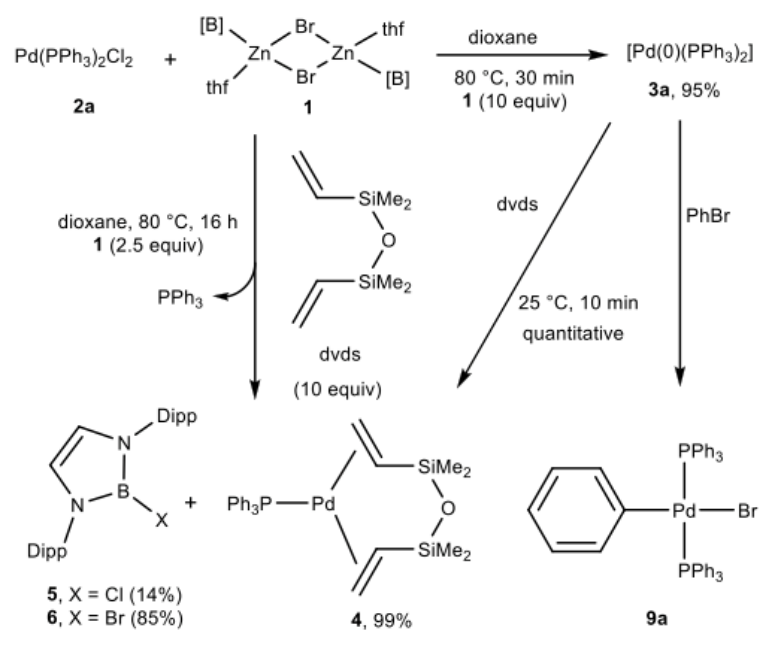

Scheme 2. Activation of $\left[\mathrm{Ph}\left(\mathrm{PPh}_{3}\right)_{2} \mathrm{Cl}_{2}\right](\mathbf{2 a})$ with $\left[(\text { thf })_{2} \mathrm{Zn} \mathrm{n}_{2}(\mathrm{Br})_{2}\left\{\mathrm{~B}(\mathrm{NDippCH})_{2}\right\}_{2}\right](\mathbf{1})$ to form $\mathrm{Pd}(0)$ active species. $[\mathrm{B}]=\left[\mathrm{B}(\mathrm{NDippCH})_{2}\right] .[\mathrm{dvds}=1,1,3,3$-tetramethyldisiloxane $]$

Accordingly, the reaction of $\mathbf{2 a}$ with 2.5 equivalents of $\mathbf{1}$ under catalytically relevant conditions (dioxane solvent, $80^{\circ} \mathrm{C}$ ) and in the presence of ten equivalents of the trapping agent 1,3-divinyl-1,1,3,3-tetramethyldisiloxane $(\mathrm{dvds})^{27}$ results in the quantitative formation of the stable $\mathrm{Pd}(0)$ monophosphine complex $\left[\mathrm{Pd}\left(\mathrm{PPh}_{3}\right)\left(\mathrm{K}^{2}-\mathrm{dvds}\right)\right]$ (4) after 16 hours, with concomitant release of one equivalent of $\mathrm{PPh}_{3}$ (Scheme 2). The reaction was monitored by ${ }^{1} \mathrm{H}$ and ${ }^{31} \mathrm{P}\left\{{ }^{1} \mathrm{H}\right\}$ NMR spectroscopy (showing 45 and $66 \%$ conversion after 2 and $4 \mathrm{~h}$, respectively) and clean formation of 4 was unambiguously confirmed by comparison with previous literature data. ${ }^{28}$ Around $40 \%$ of the borylzinc reagent 1 was converted into haloborane, in accordance with a reduction stoichiometry which requires one boryl anion equivalent per molecule of $2 a$. The haloborane generated is a ca. 1:6 ratio of chloroborane (5) and bromoborane (6), with the mixture thought to result from halide exchange between 1 and 2a. This observation is supported by the fact that the same reaction carried out over a period of $30 \mathrm{~min}$, using variable amounts of 1 (but in the absence of dvds) leads to a mixture of products that includes $\left[\mathrm{Pd}\left(\mathrm{PPh}_{3}\right)_{2} \mathrm{BrCl}\right]$ (7) and $\left[\mathrm{Pd}\left(\mathrm{PPh}_{3}\right)_{2} \mathrm{Br}_{2}\right](\mathbf{8})$ (Scheme 3). The nature of $\mathbf{7}$ and 8 was ascertained via ${ }^{1} \mathrm{H}$ and ${ }^{31} \mathrm{P}\left\{{ }^{1} \mathrm{H}\right\} \mathrm{NMR}$ spectroscopy by spiking with authentic samples synthesized following literature procedures. ${ }^{29}$ Nonetheless, under such conditions the major product (up to 95\% using 10 equiv. of 1) was the expected species $\left[\mathrm{Pd}(0)\left(\mathrm{PPh}_{3}\right)_{2}\right](3 \mathrm{a})$ (in any of its related oligomeric forms or halide adducts) ${ }^{11 a}$, characterized by a broad ${ }^{31} \mathrm{P}\left\{{ }^{1} \mathrm{H}\right\}$ NMR resonance at $\delta_{P} c a .21$ ppm. ${ }^{28,30}$ The formulation of the $\mathrm{Pd}(0)$ active species was further confirmed by 
adding dvds or bromobenzene to these reaction mixtures, which after $10 \mathrm{~min}$ at $25^{\circ} \mathrm{C}$ resulted in quantitative formation of the alkene adduct 4 or the oxidative addition product $\left[\mathrm{Ph}\left(\mathrm{PPh}_{3}\right)_{2} \mathrm{PhBr}\right](9 \mathrm{a})$, respectively. These results demonstrate that in the absence of any external additive, borylzinc $\mathbf{1}$ is able to convert $\mathbf{2 a}$ into $\operatorname{Pd}(0)$ species (e.g. 3a) under catalytically relevant conditions.

\begin{tabular}{|c|c|c|c|c|c|c|c|c|}
\hline $\mathrm{Pd}\left(\mathrm{PPh}_{3}\right)_{2} \mathrm{Cl}_{2} \quad \mathbf{2 a}$ & $\frac{\text { dioxane }}{80^{\circ} \mathrm{C}, 30 \mathrm{~min}}$ & $\begin{array}{c}\mathrm{Pd}\left(\mathrm{PPh}_{3}\right)_{2} \mathrm{Cl}_{2} \\
\mathbf{2 a}\end{array}$ & $\begin{array}{c}{\left[\mathrm{Pd}^{0}\left(\mathrm{PPh}_{3}\right)_{2}\right]} \\
\mathbf{3 a}\end{array}$ & $\begin{array}{c}\mathrm{Pd}\left(\mathrm{PPh}_{3}\right)_{2} \mathrm{BrCl} \\
\mathbf{7}\end{array}$ & $\begin{array}{c}\mathrm{Pd}\left(\mathrm{PPh}_{3}\right)_{2} \mathrm{Br}_{2} \\
\mathbf{8}\end{array}$ & $\begin{array}{c}\mathrm{Pd}\left(\mathrm{PPh}_{3}\right)_{2} \mathrm{PhBr} \\
\mathbf{9 a}\end{array}$ & $\begin{array}{c}{\left[\mathrm{PPh}_{4}\right] \mathrm{ZnX} \mathrm{X}_{3}} \\
10\end{array}$ & $\begin{array}{c}{[\mathrm{Pd}]_{3}} \\
11\end{array}$ \\
\hline & 0.5 equiv & 8 & - & $12 \%$ & $6 \%$ & $6 \%$ & $15 \%$ & $60 \%$ \\
\hline & 1.5 equiv & 1 & $48 \%$ & $1 \%$ & $1 \%$ & $1 \%$ & $8 \%$ & $42 \%$ \\
\hline 1 & 2.5 equiv & - & $58 \%$ & - & - & $<1 \%$ & $6 \%$ & $22 \%$ \\
\hline & (10 equiv & - & $95 \%$ & - & - & - & - & - \\
\hline
\end{tabular}

Scheme 3. Reaction of pre-catalyst $2 \mathrm{a}$ with variable amounts of borylzinc $1\left({ }^{31} \mathrm{P}\left\{{ }^{1} \mathrm{H}\right\}\right.$ NMR spectroscopic yields calculated relative to total phosphorus content). $[\mathrm{Pd}]_{3}(\mathbf{1 1})=\left[\left(\mathrm{Ph}_{3} \mathrm{P}\right)_{3} \mathrm{Pd}_{3}\left(\mu-\mathrm{PPh}_{2}\right)_{2}(\mu-\mathrm{Br})\right]^{+}$.

Another interesting aspect observed during reactions of $\mathbf{1}$ and $\mathbf{2 a}$ is the non-innocent character of the $\mathrm{PPh}_{3}$ ligands in experiments performed under related conditions using fewer equivalents of $\mathbf{1}$ (Scheme 3 ). Under such conditions, we could identify $\left[\mathrm{Pd}\left(\mathrm{PPh}_{3}\right)_{2} \mathrm{PhBr}\right](\mathbf{9 a})$ and $\left[\mathrm{PPh}_{4}\right]^{+}(\mathbf{1 0})$ even in the absence of bromobenzene, as minor species in variable amounts (the identities of which were confirmed by spiking with authentic standards). Moreover, even in the absence of any organic substrate to be borylated, phenylborane (12) is still formed in yields of around 20 to $30 \%$ relative to $2 \mathrm{a}$. Cleavage of $\mathrm{P}-\mathrm{C}$ bonds within phosphine ligands mediated by palladium has precedent in the literature, and has been associated with catalyst deactivation processes. ${ }^{31}$ One of the suggested mechanisms involves the formation of multimetallic species containing phosphide bridges after oxidative addition of a P-C bond at an adjacent metal centre. ${ }^{32} \mathrm{~A}$ similar mechanism of this kind (Scheme 4), which is also supported by calculations (vide infra), would be consistent with the subsequent formation of species $9 a$ and $\mathbf{1 1} .10$ could then be formed by reductive elimination of $\left[\mathrm{PPh}_{4}\right]^{+}$from $9 a .{ }^{33} \mathrm{At}$ low ratios of borylzinc reagent 1 (vs. palladium precursor $\mathbf{2 a}$ ), the $\mathrm{Pd}(0)$ species $3 \mathbf{a}$ could comproportionate with asyet unreacted $2 \mathrm{a}$ to generate a Pd dimer, which would evolve into products $9 a, 10,11$ or 12 following a variety of elementary steps. In addition, the formation of these products by initial comproportionation of $\operatorname{Pd}(0)$ and $\operatorname{Pd}(I I)$ is consistent with their non-observation in experiments where 3a is trapped using dvds (Scheme 2). In contrast, under higher concentrations of borylzinc reagent 1 (e.g. 10 equiv.) Pd(II) precursor 2 a would rapidly be consumed resulting in clean and almost quantitative formation of $3 a$. 


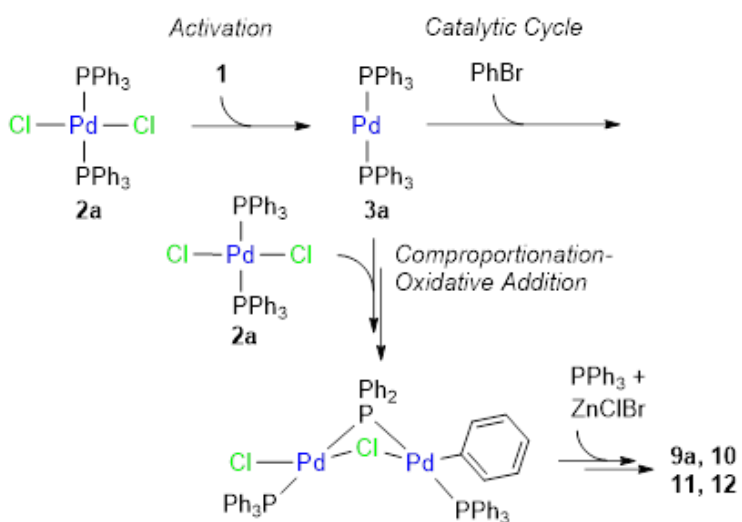

Scheme 4. Proposed mechanism for the activation of $\mathrm{PPh}_{3}$ by means of $\mathrm{P}-\mathrm{C}$ cleavage via formation of a Pd dimer.

Interestingly, during these experiments using lower concentrations of 1 we could also observe a characteristic pattern of ${ }^{31} \mathrm{P}\left\{{ }^{1} \mathrm{H}\right\}$ resonances due to an $\mathrm{ABB}^{\prime} X X^{\prime}$ spin system $\left(\delta_{X}=226.5, \delta_{B}=19.0\right.$ and $\delta_{A}=12.3 \mathrm{ppm} ; J_{A X}=11$, $J_{A B}=91 \mathrm{~Hz}$ ). The species responsible (11) can be obtained in spectroscopic yields of up to $60 \%$ by heating dioxane solutions of 1 and 2 a (in a $2: 1$ ratio) at $80^{\circ} \mathrm{C}$ for $30 \mathrm{~min}$. Increasing the amount of 1 relative to $2 a$ decreases the amount of $\mathbf{1 1}$ produced in favour of $\left[\mathrm{Pd}(0)\left(\mathrm{PPh}_{3}\right)_{2}\right]$ (3a) (Scheme 3). Intense red crystals of 11 could be grown from dichloromethane/hexane solutions and X-ray diffraction studies reveal that the palladiumcontaining component is the trinuclear bis-phosphide $\left[\left(\mathrm{Ph}_{3} \mathrm{P}\right)_{3} \mathrm{Pd}_{3}\left(\mu-\mathrm{PPh}_{2}\right)_{2}(\mu-\mathrm{Br})\right]^{+}$(Figure 2). The unit cell contains two of these tri-palladium units co-crystallized with one $\left[\mathrm{PPh}_{4}\right]^{+}$cation (thus further confirming its formation during pre-catalyst activation), with charge balance being achieved via a rare $\left[\mathrm{Zn}_{6} \mathrm{Cl}_{15}\right]^{3-}$ anionic cluster (see Supporting Information for details). The tripalladium cluster might be seen as an intermediate state during pre-catalyst reduction, with an average metal oxidation state of 4/3.

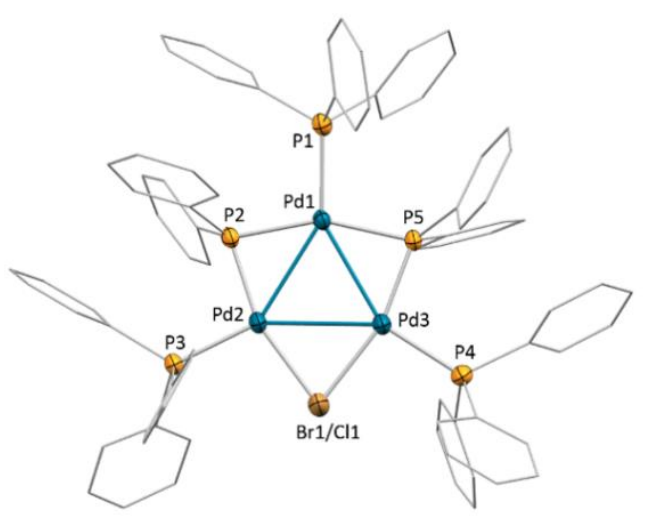

Figure 2. ORTEP diagram of cationic trinuclear component of $\mathbf{1 1}$ (thermal ellipsoids: $\mathbf{5 0 \%}$ probability; $\mathrm{H}$ atoms, one of the two 11 cations present in the unit cell and $\left[\mathrm{Zn}_{6} \mathrm{Cl}_{15}\right]^{3-}$ counter-anion omitted and phenyl groups shown in wireframe format for clarity).

It is noteworthy that an almost identical trinuclear palladium phosphide (with the exception of the bridging halide ligand and counter-anion) was reported by Dixon and co-workers to be formed on prolonged heating of thf solutions of $\left[\mathrm{Pd}\left(\mathrm{PPh}_{3}\right)_{3} \mathrm{Cl}\right]\left[\mathrm{BF}_{4}\right] .{ }^{31,34}{ }^{31} \mathrm{P}\left\{{ }^{1} \mathrm{H}\right\} \mathrm{NMR}$ spectroscopic and X-ray diffraction data closely match those measured for 11. Despite the extensive use of $\left[\mathrm{Pd}\left(\mathrm{PPh}_{3}\right)_{3} \mathrm{Cl}_{2}\right](\mathbf{2 a})$ as a pre-catalyst, this is to our knowledge the 
first time that such a palladium phosphide cluster has been observed during a catalytic cross-coupling reaction. Its potential role during catalysis will be further discussed below.

Regarding the formation of phenylborane $\mathbf{1 2}$ during these experiments, it is also important to note that the $\left[\mathrm{PPh}_{4}\right]^{+}$cation generated as per Scheme 4 could serve as one of the sources of $\mathbf{1 2}$, as has previously been reported for a related C-C cross-coupling protocol..$^{35}$ Indeed, we could demonstrate that $\mathbf{1}$ is able to borylate $\left[\mathrm{PPh}_{4}\right]^{+}(\mathbf{1 0})$ in the presence of $\mathbf{2 a}$ to form phenylborane $\mathbf{1 2}$ and $\mathrm{PPh}_{3}$ in yields of around $10 \%$ (Scheme 5 ). The low yield is attributed to catalyst poisoning by the released $\mathrm{PPh}_{3}$, in agreement with control experiments discussed below.

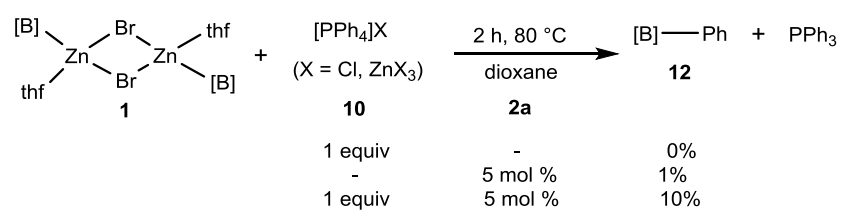

Scheme 5. Borylation of the tetraphenylphosphonium cation using 1.

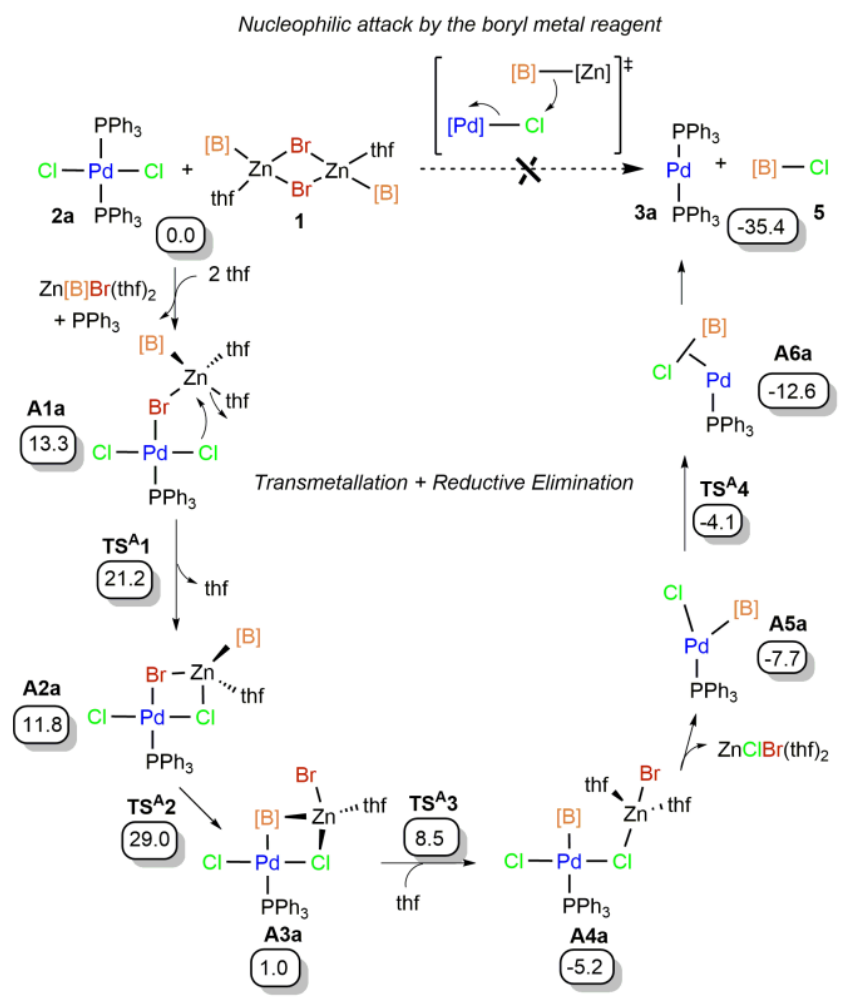

Scheme 6. Mechanisms explored for the pre-catalyst activation of $\mathbf{2 a}$ by $\mathbf{1}$ with free energies in $\mathrm{kcal} \mathrm{mol}^{-1}$.

In order to obtain further insight into the pathways involved in the activation of the Pd pre-catalyst 2a, DFT calculations were carried out using the M06L and M06 functionals and mixed implicit-explicit models for THF solvation (see Computational Details). The mechanism considered for the reduction of $\operatorname{Pd}(I I)$ to $\operatorname{Pd}(0)$ and formation of $[\mathrm{B}]-\mathrm{Cl}(\mathbf{5})\left([\mathrm{B}]=\left[\mathrm{B}(\mathrm{NDippCH})_{2}\right]\right)$ was transmetalation followed by reductive elimination (Scheme 6). This mechanism is the one proposed for the reduction of $\mathrm{Pd}(\mathrm{II})$ in most cross-coupling reactions from $\mathrm{R}-\mathrm{Pd}-\mathrm{X}$ intermediates ${ }^{11 a, 36}$ and it has been experimentally and computationally validated for Negishi reactions using $\mathrm{ZnMe}_{2}$ and $\mathrm{ZnMeCl} .{ }^{12 e, l}$ We additionally considered the possibility of direct nucleophilic attack at chloride by $\mathrm{Zn}[\mathrm{B}] \mathrm{Br}(\mathrm{thf})_{2}$ (itself generated by the fragmentation of 1 ), which has been suggested for related systems. ${ }^{37}$ 
However, all attempts to find a transition state were unsuccessful and lead us to exclude this potential pathway (see Supporting Information for more details).

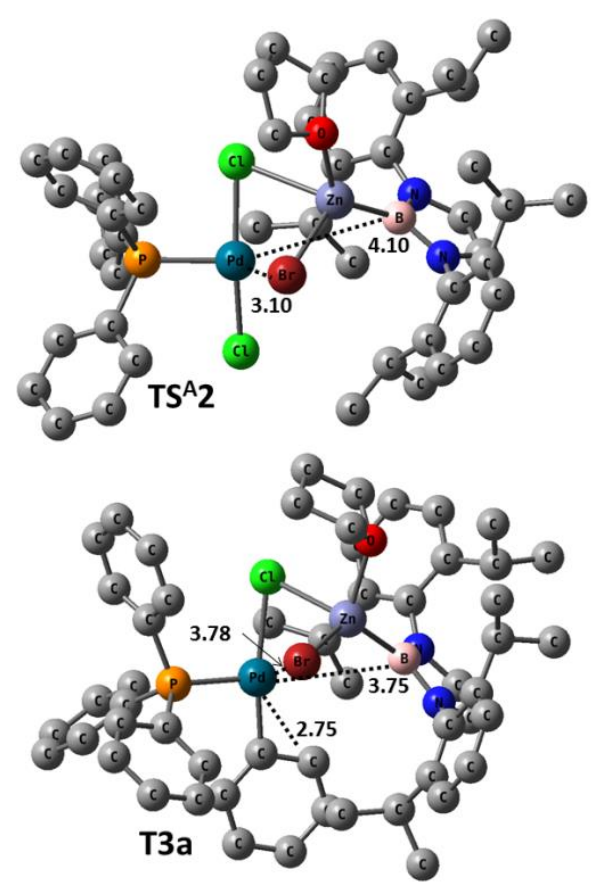

Figure 3: Geometries of $\mathbf{T S}^{\mathrm{A}} \mathbf{2}$ and T3a showing key distances. Hydrogen atoms have been removed for clarity.

Coordination of $\mathrm{Zn}[\mathrm{B}] \mathrm{Br}(\text { thf })_{2}$ was only found to be possible trans to $\mathrm{PPh}_{3}$ due to the steric bulk of the boryl ligand $[\mathrm{B}]$ (Scheme 6). Consistent with experimental observations (vide infra), this necessarily implies dissociation of one of the phosphines from $\mathbf{2 a}$, as suggested with other precatalysts of the type $\left[\left(R_{3} P\right)_{2} P d^{\prime \prime}(X)_{2}\right]$ bearing bulky phosphines, ${ }^{38}$ and formation of A1a. The substitution of one phosphine by the borylzinc fragment is endoergic by $13.3 \mathrm{kcal} \mathrm{mol}^{-1}$. Substitution of one of the zinc-bound thf ligands by chloride has an energetic barrier of $7.9 \mathrm{kcal} \mathrm{mol}^{-1}\left(\mathrm{TS}^{\mathrm{A}} \mathbf{1}\right)$ and stabilizes this intermediate by $1.5 \mathrm{kcal} \mathrm{mol}^{-1}$. Subsequent formation of the $\mathrm{Pd}$-boryl bond in $\mathrm{A3a}\left(\Delta \mathrm{G}=1.0 \mathrm{kcal} \mathrm{mol}^{-1}\right)$ requires decomplexation of $\mathrm{Br}$ followed by rotation of the $\mathrm{Cl}-$ $\mathrm{Zn}[\mathrm{B}] \mathrm{Br}$ (thf) bond. A transition state for this process ( $\mathbf{T S}^{\mathrm{A}} \mathbf{2}$, Figure 3) was located with a free energy of $29.0 \mathrm{kcal}$ $\mathrm{mol}^{-1}$ above the initial reactants, which is consistent with the high temperature $\left(80^{\circ} \mathrm{C}\right)$ required for catalyst activation. In A3a, the boryl group is bound to both Pd and Zn, with Pd-B and B-Zn distances of 2.09 and $2.81 \AA$, respectively. The latter interaction is lost in the subsequent step, in which the boryl group is displaced at zinc by an external thf molecule through $\mathrm{TS}^{\mathrm{A}} \mathbf{3}\left(\Delta \mathrm{G}=8.5 \mathrm{kcal} \mathrm{mol}^{-1}\right)$. The overall transmetalation process is exergonic by $5.2 \mathrm{kcal} \mathrm{mol}^{-1}$. Subsequent dissociation of $\mathrm{ZnBrCl}(\text { thf })_{2}$ yields the unsaturated $\mathrm{Pd}$ intermediate $\mathbf{A 6 a}$, which by reductive elimination forms $[\mathrm{B}]-\mathrm{Cl}$. This reaction has a low energy barrier $\left(3.6 \mathrm{kcal} \mathrm{mol}^{-1}\right)$ and is exergonic by 4.9 kcal mol${ }^{-1}$ if [B]-Cl remains bonded to $\mathrm{Pd}(\mathrm{A} 7 \mathrm{a})$, and by $27.7 \mathrm{kcal} \mathrm{mol}^{-1}$ if the chloroborane is displaced by $\mathrm{PPh}_{3}$ to give $\mathrm{Pd}(0)\left(\mathrm{PPh}_{3}\right)_{2}$.

To provide further evidence for the essential role of phosphine dissociation during the transmetalation process that leads to precatalyst activation, we additionally performed one of the experiments described in Scheme 3 (2.5 equiv. of 1 ) in parallel with an identical experiment in which 2.5 equiv. of $\mathrm{PPh}_{3}$ were added to the mixture. 
While the former solution rapidly turned dark red due to the formation of tripalladium compound $\mathbf{1 1}$, the reaction containing additional $\mathrm{PPh}_{3}$ remained bright yellow even after several hours at $80 \stackrel{\circ}{ } \mathrm{C}$. Both reaction mixtures were monitored by ${ }^{1} \mathrm{H}$ and ${ }^{31} \mathrm{P}\left\{{ }^{1} \mathrm{H}\right\} \mathrm{NMR}$, revealing full consumption of precatalyst $2 \mathrm{a}$ after $\mathrm{ca}$. one hour at $80^{\circ} \mathrm{C}$ in the absence of added $\mathrm{PPh}_{3}$, but only $10 \%$ consumption (and $90 \%$ unchanged $\mathbf{2 a}$ ) in the presence of $\mathrm{PPh}_{3}$.

In addition, the dissociation of phosphine is consistent with the reduced activity observed when using $\left[\mathrm{Pd}(\mathrm{dppf}) \mathrm{Cl}_{2}\right]\left(\mathrm{dppf}=1,1^{\prime}\right.$-bis(diphenylphosphino)ferrocene) instead of $\left[\mathrm{Pd}\left(\mathrm{PPh}_{3}\right)_{2} \mathrm{Cl}_{2}\right](2 \mathrm{a})$ as the pre-catalyst, ${ }^{6}$ and with the formation of phosphonium salts during the reaction of $\mathbf{2 a}$ with $\mathbf{1}$ (Scheme 3). As described above, the formation of $\left[\mathrm{PPh}_{4}\right]^{+}$and $9 \mathrm{a}$ suggests the presence of facile routes for the oxidative addition of $\mathrm{P}$-Ph bonds. We found that this reaction from the unsaturated $\mathrm{Pd}(\mathrm{II})$ and $\mathrm{Pd}(0)$ intermediates $\mathbf{A 6 a}$ and $\mathbf{A 7 a}$ is either not feasible or endergonic by $17 \mathrm{kcal} \mathrm{mol}^{-1}$, respectively. By contrast, an oxidative P-C bond cleavage reaction at dimer D1a, (itself formed by coordination of $\mathbf{2 a}$ to $\mathrm{Pd}(0)-\mathrm{PPh}_{3}$ as proposed in Scheme 4 ) is exergonic ( $\Delta \mathrm{G}=-3.7$ $\left.\mathrm{kcal} \mathrm{mol}^{-1}\right)$ and has a low energy barrier (11.4 $\mathrm{kcal} \mathrm{mol}^{-1}$ from D2a). This reaction takes place in two consecutive steps involving comproportionation, in which one $\mathrm{Ph}$ group of a phosphine ligand assists the $\mathrm{Pd}(0)$ to $\mathrm{Pd}(\mathrm{II})$ oxidation, followed by $\mathrm{P}-\mathrm{Ph}$ oxidative addition involving the same $\mathrm{Ph}$ group. Oxidative addition of $\mathrm{C}-\mathrm{X}$ and $\mathrm{Y}-\mathrm{H}$ bonds $(X=$ halogen, and $\mathrm{Y}=\mathrm{H}, \mathrm{O}, \mathrm{N})$ to $\mathrm{Pd}(\mathrm{I})-\mathrm{Pd}(\mathrm{I})$ dimers has precedent in the literature. ${ }^{39}$ The formation of dimeric species D1a, D2a and D3a is endergonic by 8.6, 5.8 and $4.9 \mathrm{kcal} \mathrm{mol}^{-1}$, respectively, and indeed none of these species have ever been observed during reactions of $\mathbf{1}$ and $\mathbf{2 a}$. Instead, the products experimentally characterized are 9a, 10, 11 and $\mathbf{1 2}$ (Scheme 3), presumably formed by further reactions of D3a with $\mathrm{ZnX}_{2}$ and $\mathrm{PPh}_{3}$.

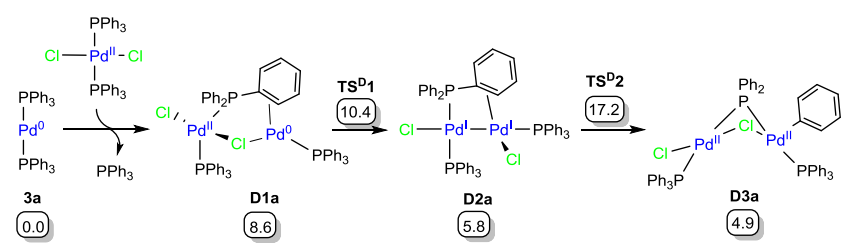

Scheme 7. Mechanism for the oxidative addition of a $\mathrm{P}-\mathrm{Ph}$ bond derived from $\left[\mathrm{Pd}(\mathrm{O})\left(\mathrm{PPh}_{3}\right)_{2}\right]$ and $\mathrm{Pd}\left(\mathrm{PPh}_{3}\right)_{2} \mathrm{Cl}_{2}$ via formation of a dinuclear Pd complex. Free energies in $\mathrm{kcal} \mathrm{mol}^{-1}$.

\section{Oxidative addition}

We previously observed that $2 \mathrm{a}$ was the catalyst of choice for the borylation of bromobenzene (95\% yield after $2 \mathrm{~h}$ reaction at $\left.80^{\circ} \mathrm{C}\right)$, while its tri(o-tolyl) phosphine counterpart $\left[\mathrm{Pd}\left(\mathrm{P}(\mathrm{o}-\mathrm{Tol})_{3}\right)_{2} \mathrm{Cl} 2\right](\mathbf{2 b})$ was barely active $(12 \%$ yield under identical conditions), and rapidly decomposed to form Pd-black (Scheme 8). ${ }^{6}$ By contrast, the borylation of benzoyl chloride proceeded to a similar extent with both systems.

Oxidative addition at $\left[\mathrm{Pd}(0)\left(\mathrm{PAr}_{3}\right)_{2}\right]$ moieties is well known and several experimental and computational studies have focused on this process. ${ }^{35}$ We have experimentally observed that the reactions of bromobenzene or benzoyl chloride with freshly generated $\left[\mathrm{Pd}(0)\left(\mathrm{PPh}_{3}\right)_{2}\right](3 \mathrm{a})$ proceed cleanly and extremely rapidly (Scheme 2 ). Moreover, DFT calculations show that the oxidative addition of benzoyl chloride at either $\mathbf{3 a}$ or $\mathbf{3 b}$ is favoured thermodynamically by 19.1 and $3.6 \mathrm{kcal} \mathrm{mol}^{-1}$, respectively (Scheme 9). However, while the reaction of bromobenzene and $\mathbf{3 a}$ is also exoergic $\left(\Delta \mathrm{G}=-14.7 \mathrm{kcal} \mathrm{mol}^{-1}\right)$ the analogous process involving $\mathbf{3 b}$ is almost thermoneutral $\left(\Delta G=0.6 \mathrm{kcal} \mathrm{mol}^{-1}\right.$ ), leading indeed to a bridging dipalladium species with concomitant release of a phosphine ligand. ${ }^{35 b}$ This is consistent with the reversible oxidative addition of bromobenzene at $\mathbf{3 b}$, with 
the differences compared to 3a presumably being due to steric considerations. This equilibrium, along with the fact that the subsequent transmetalation step seems to be rate-limiting (vide infra) is presumably therefore responsible for pre-catalyst decomposition to palladium black in the system $\mathrm{Ar}-\mathrm{Br} / \mathbf{3 b}$. By contrast, the irreversible oxidative addition to $3 a$ of bromobenzene stabilizes the $\mathrm{Pd}(\mathrm{II})$ component in the form of $9 \mathrm{a} .{ }^{40}$

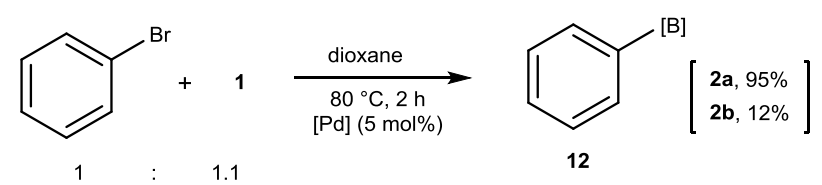

Scheme 8 . Borylation of bromobenzene using pre-catalysts $\mathbf{2} \mathbf{a}$ and $\mathbf{2} \mathbf{b}$.

(i)

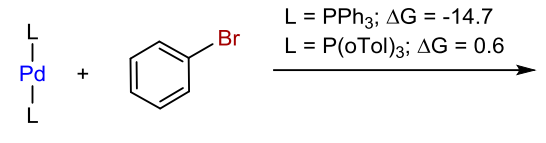

(ii)

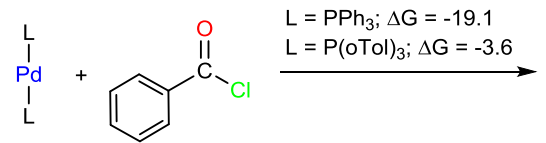

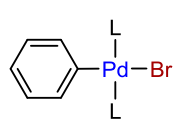

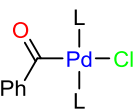

Scheme 9. Free energies in $\mathrm{kcal} \mathrm{mol}^{-1}$ for the oxidative addition of (i) $\mathrm{PhBr}$ and (ii) $\mathrm{PhCOCl}$ with $\mathrm{L}=\mathrm{PPh}_{3}$ and $\mathrm{L}=$ $\mathrm{P}(\mathrm{o}-\mathrm{Tol})_{3}$.

\section{Transmetalation of borylzinc reagents}

Transmetalation is a critical step in cross-coupling reactions and occurs via a variety of mechanisms owing to the broad variety of nucleophiles employed. ${ }^{41}$ Following the commonly cited catalytic cycle, transmetalation would be expected to take place at a $\mathrm{Pd}(\mathrm{II})$ complex itself derived from the oxidative addition of bromobenzene or benzoyl chloride to a $\left[\mathrm{Pd}(0)\left(\mathrm{PAr}_{3}\right)_{2}\right]$ species. From the intermediate $\mathrm{Pd}(\mathrm{II})$ complex, a mechanism analogous to that shown in Scheme 6 might then be expected to be responsible for introduction of the boryl ligand into the coordination sphere of palladium, followed by B-C reductive elimination. To probe this hypothesis, we performed stoichiometric reactions between the previously synthesized oxidative addition products $9 \mathrm{a}$ (from bromobenzene) or 14a (from benzoyl chloride) and borylzinc reagent 1 under catalytically relevant conditions (Scheme 10). As expected, these reactions led efficiently to the formation of the borylated organic compounds $\mathrm{PhB}(\mathrm{NDippCH})_{2}(\mathbf{1 2})$ and $\mathrm{PhC}(\mathrm{O}) \mathrm{B}(\mathrm{NDippCH})_{2}(\mathbf{1 3})$, as well as $\left[\mathrm{Pd}(0)\left(\mathrm{PPh}_{3}\right)_{2}\right](3 \mathrm{a})$. Notably, the ratio of 12 to 13 obtained from the stoichiometric reaction of 14a with 1 (ca. 1.6:1) is identical to that obtained from catalytic reactions using pre-catalyst $\left[\mathrm{Pd}\left(\mathrm{PPh}_{3}\right)_{3} \mathrm{Cl}_{2}\right](2 \mathrm{a})$ (see Scheme 8 ), thus suggesting that $14 \mathrm{a}$ is indeed a competent intermediate during catalysis. In this reaction, $\mathbf{1 2}$ is potentially formed via $\mathrm{CO}$ extrusion from 14a brought about by phosphine ligand dissociation (see Supporting Information for details). 


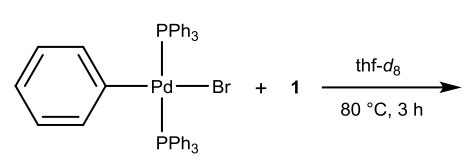

9a

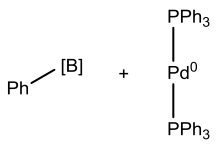

$12 \quad 3 a$

(B)

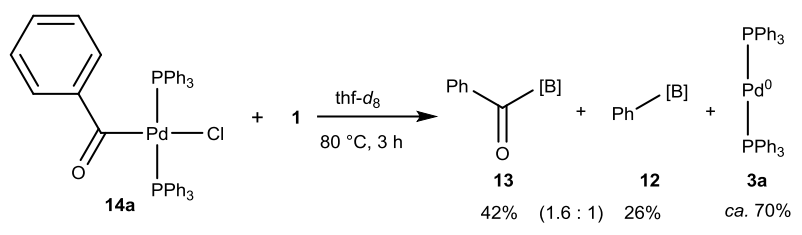

The viability of $9 \mathbf{a}$ and $\mathbf{1 4 a}$ as intermediate species in the catalytic cycle was further confirmed by comparison of their catalytic profiles with that of pre-catalyst $\mathbf{2} \mathbf{a}$ for the borylation of bromobenzene and benzoyl chloride, respectively. To do so, we monitored the catalytic performance of the three palladium species in parallel by ${ }^{1} \mathrm{H}$ and ${ }^{11} \mathrm{~B}\left\{{ }^{1} \mathrm{H}\right\}$ NMR spectroscopy: Figure 4 shows temporal profiles for each system (derived from ${ }^{1} \mathrm{H}$ NMR measurements) based on the consumption of the borylzinc reagent 1 (see Experimental Section for details). The catalytic behaviour of intermediates $\mathbf{9 a}$ and $\mathbf{1 4 a}$ is almost identical to (or even slightly superior than) that of precatalyst $\mathbf{2 a}$, a finding which clearly supports their roles as intermediates in the catalytic cycle. We additionally assayed the trinuclear system $\mathbf{1 1}$ as a catalyst for the borylation of bromobenzene and found a slightly diminished but comparable catalytic performance to that of $\mathbf{2 a}$ and $9 a$. An induction period of around $10 \mathrm{~min}$ became evident for $\mathbf{1 1}$ to become active, which we associate with its break-up into active mononuclear $\operatorname{Pd}(0)$ species.
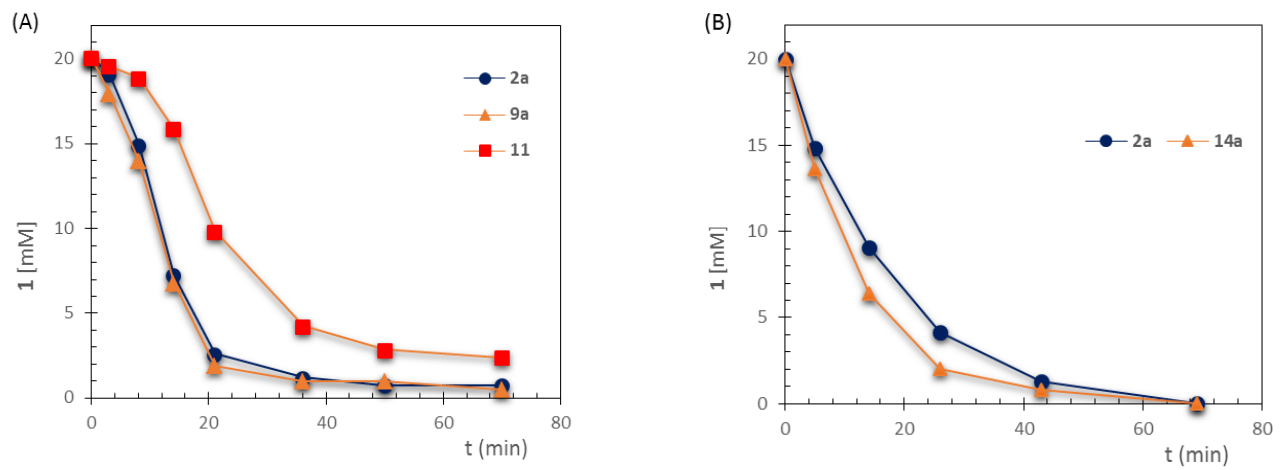

Figure 4. Reaction profiles for the borylation of bromobenzene $(A)$ and benzoyl chloride (B) using pre-catalyst 2a, oxidative addition intermediates $9 a$ and $14 a$ and trimetallic-Pd 11. Reaction conditions: Reaction conditions: $1(0.010 \mathrm{mmol})$, bromobenzene or benzoyl chloride $(0.022 \mathrm{mmol})$, [Pd] (5 mol\%), solvent (0.5 $\mathrm{mL}$; 1,4-dioxane (A) or thf (B)), $80^{\circ} \mathrm{C}$. Reaction monitoring by ${ }^{1} \mathrm{H}$ NMR spectroscopy using an internal standard. Lines drawn to guide the eye.

At first inspection, it seems likely that transmetalation is the rate limiting step in the catalytic cycle since the stoichiometric oxidative addition step is rapid, while no palladium boryl species can be detected after transmetalation. At the very least, the implication is that transmetalation must occur at a significantly slower rate than subsequent reductive elimination in order that the concentrations of palladium boryl intermediates never accumulate to levels detectable by NMR. Given the trans disposition of the aryl/acyl and halide ligands in 9a/14a we therefore decided to investigate whether the change to a cis disposition of aryl/acyl and boryl groups required for reductive elimination was occurring during the transmetalation step via ligand dissociation (as shown in Scheme 6). As an initial probe, we examined the reactions towards borylzinc reagent 1 of 
palladium complexes 15 and 16, which feature chelating phosphines, and consequently cis oriented aryl/acyl and halide ligands. Despite being electronically similar to $9 a$ and $14 a$, however, formation of the borylated products proceeded at a considerably slower rate with 15/16 (Scheme 11). It seems likely (given that 15 and 16 are stereochemically pre-organized with respect to subsequent C-B reductive elimination), that it is a slower rate of transmetalation for these chelating systems which underpins this difference. This in turn can be ascribed to the high steric encumbrance around the palladium centre which would result from accommodating not only the two tertiary phosphine co-ligands but also the massively hindered boryl group. In the case of 9a/14a featuring monodentate co-ligands - the potential for phosphine dissociation during transmetalation would reduce the degree of crowding in a manner less readily accessible to $\mathbf{1 5}$ and $\mathbf{1 6}$ due to the chelate effect conferred by the bisphosphine. Consistently, the necessity for phosphine dissociation (which was also suggested for similar mechanistic steps during pre-activation) is further implied by examining the effects on the $9 a+1$ temporal profile of the presence of two additional equivalents of triphenylphosphine. Thus, the rate of consumption of $\mathbf{1}$ is very clearly inhibited by the presence of additional phosphine (Figure 5).

Scheme 11. Reaction of P(II) complexes 15 and 16 bearing chelating 1,2-(diphenylphosphino)benzene with borylzinc 1.

These findings are in marked contrast with related studies of Negishi C-C coupling reactions using organozinc reagents of reduced steric demands compared to borylzinc $\mathbf{1}$, for which phosphine dissociation is not a prerequisite for transmetalation to occur. ${ }^{12 e, l}$ Moreover, it has been observed that transmetalation with $\mathrm{ZnMe}_{2}$ is faster than with $\mathrm{ZnMeCl}$ in classic Negishi reactions, ${ }^{12 e}$ while our studies reveal that bisboryl compound $\mathrm{Zn}\left\{\mathrm{B}(\mathrm{NDippCH})_{2}\right\}_{2}$ is barely active for the borylation of aryl bromides and acyl chlorides, most likely due to steric reasons. ${ }^{6}$ An additional advantage derived from the use of highly bulky borylzinc reagents is that no B-B homocoupling is detected - as often observed with organozinc reagents in Negishi reactions. ${ }^{42}$ The critical

(A)

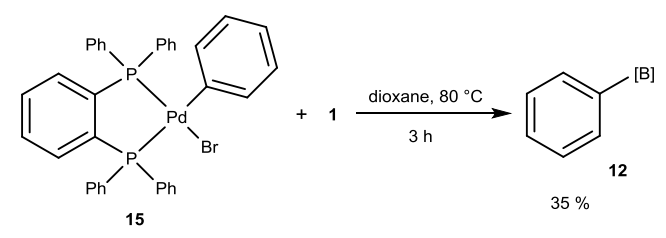

(B)

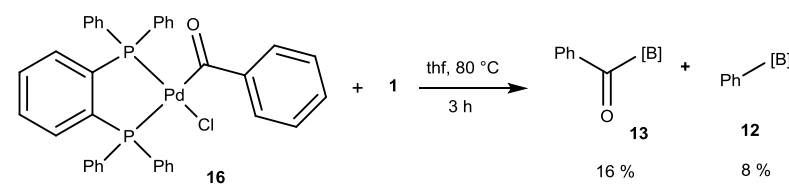

influence of sterics in our system can also be inferred from the considerably slower rates of borylation of orthosubstituted aryl bromides compared to bromobenzene. ${ }^{6}$

Also consistent with the necessity for phosphine dissociation, is the fact that in situ ${ }^{31} \mathrm{P}\left\{{ }^{1} \mathrm{H}\right\} \mathrm{NMR}$ spectroscopic analyses during catalytic runs using $2 \mathrm{a}$ reveal resonances at $\delta_{\mathrm{P}} c a .30 \mathrm{ppm}$ which we tentatively assign to monoligated species of general formula $\left[\mathrm{Pd}\left(\mathrm{PPh}_{3}\right) \mathrm{PhX}\right]_{2}(\mathrm{X}=\mathrm{Cl}, \mathrm{Br})$, based on literature precedent $\left(\left[\mathrm{Pd}\left(\mathrm{PPh}_{3}\right) \mathrm{PhX}\right]_{2}, \delta_{\mathrm{P}}\right.$

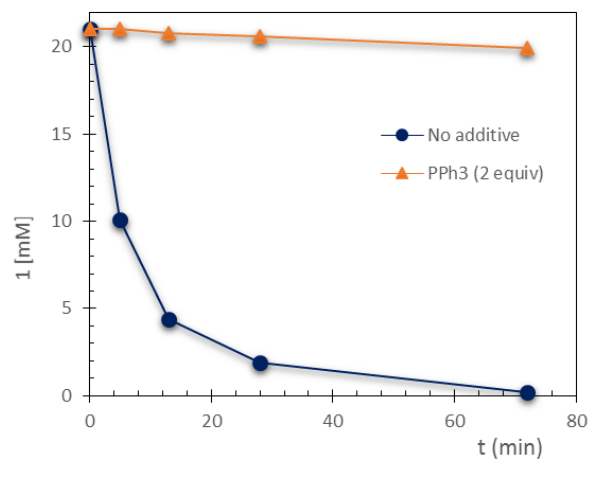


$\left.\mathrm{X}=\mathrm{Cl}\left\{\mathrm{CD}_{2} \mathrm{Cl}_{2}: 31.6 \mathrm{ppm}\right\}, \mathrm{X}=\mathrm{Br}\left\{\mathrm{CD}_{2} \mathrm{Cl}_{2}: 30.4, \mathrm{C}_{6} \mathrm{D}_{6}: 30.7\right\} ;\left[\mathrm{Pd}\left(\mathrm{PPh}_{3}\right) \mathrm{PhX}\right]_{2}\right]^{\prime}, \delta_{\mathrm{P}} \mathrm{X}=\mathrm{Cl}\left\{\mathrm{CD}_{2} \mathrm{Cl}_{2}: 30.9 \mathrm{ppm}\right\}, \mathrm{X}=\mathrm{Br}$ $\left.\left\{\mathrm{CD}_{2} \mathrm{Cl}_{2}: 29.9, \mathrm{C}_{6} \mathrm{D}_{6}: 30.5\right\}\right) .{ }^{43}$ These species are only ever present in low concentration $(<20 \%)$ and the associated NMR signals disappear after reaction completion.

Figure 5. Reaction profile for the reaction between $\left[\mathrm{Pd}\left(\mathrm{PPh}_{3}\right)_{2} \mathrm{PhBr}\right](9 \mathrm{9})$ and borylzinc reagent 1 in the absence (blue circle) and the presence (orange triangle) of added $\mathrm{PPh}_{3}$ (2 equiv). Reaction conditions: 1 (0.011 mmol), bromobenzene $(0.024 \mathrm{mmol}), 2 \mathrm{a}(5 \mathrm{~mol} \%)$, additional $\mathrm{PPh}_{3}(10 \mathrm{~mol} \%), 1,4$-dioxane $(0.5 \mathrm{~mL}), 80^{\circ} \mathrm{C}$. Reaction monitoring by ${ }^{1} \mathrm{H}$ NMR spectroscopy using an internal standard. Lines drawn to guide the eye.

In addition to these experiments, we also wanted to determine by means of calculations the feasibility of a transmetalation mechanism occurring via intermediates similar to those proposed for the pre-catalyst activation step. With this in mind, the structures/energies for species shown in Scheme 6 were computed by replacing one of the chlorides by $\mathrm{Ph}\left(\mathbf{1 5}^{\mathrm{cl}}\right)$. The relevant calculated energies are shown in Scheme 12 . The free energies of all intermediates in which zinc-containing species are bound to Pd are higher with Ph (T1a-T5a) than with $\mathrm{Cl}$ (A1a-A4a). This is consistent with the lower electrophilicity expected for complexes of the type [PdL $\left.\mathrm{RCl}_{2}\right]$ compared to $\left[\mathrm{PdL}_{2} \mathrm{Cl}_{2}\right]$, together with the higher steric profile of $\mathrm{Ph}$ compared to $\mathrm{Cl}$. However, once $\mathrm{ZnBrCl}(\operatorname{thf})_{2}$ is dissociated from intermediate T5a, direct formation of $\mathrm{Ph}$ - $[\mathrm{B}]$ takes place without any apparent energy barrier and is strongly exergonic ( $\Delta \mathrm{G}=-44.6 \mathrm{kcal} \mathrm{mol}^{-1}$ ). Indeed a small gain in energy of $2.5 \mathrm{kcal} \mathrm{mol}^{-1}$ is observed by replacing the $\mathrm{Ph}-[\mathrm{B}]$ by $\mathrm{PPh}_{3}$. Attempts to calculate the transition state for the bromide/boryl ligand exchange in $\mathrm{Pd}$, which is expected to be the one with the highest energy, were unsuccessful. Indeed a similar geometry to that of $\mathrm{TS}^{\mathrm{A}} \mathbf{2}$, was found to be a minimum with $\mathrm{Ph}$ instead of $\mathrm{Cl}$ (T3a, Figure 3) probably due to an interaction between a $\pi-\mathrm{CC}$ bond of $\mathrm{Ph}$ with $\mathrm{Pd}$ (which is not possible with $\mathrm{Cl}$ ). The energy of this intermediate is $24.5 \mathrm{kcal}$ $\mathrm{mol}^{-1}$ above $\mathbf{1 5}^{\mathrm{Cl}}$ and $\mathbf{1}$, and the transition states connecting it with $\mathbf{T 2}$ a and $\mathbf{T} \mathbf{4 a}$ (TS $\mathbf{T S}^{\mathrm{f}}$ and $\mathbf{T S}^{\top} \mathbf{2}^{f}$ respectively) were estimated to be 27.2 and $26.4 \mathrm{kcal} \mathrm{mol}^{-1}$ above the reactants, respectively (see supporting information). These energies suggest that a transmetalation pathway involving species T1a-T5a is reasonable for a reaction that takes place at $80^{\circ} \mathrm{C}$. It is also consistent with the fact that electron deficient aryl rings are borylated at lower rates, ${ }^{6}$ which could be understood in terms of higher energies for intermediates alike T3a and their associated transition states. Moreover, the fact that no boryl intermediates are observed at any point in the reaction sequence is consistent with the effectively barrier-less (or very low barrier) C-B reductive elimination step leading to product formation.

\section{Complete mechanistic cycle}

Overall, the results obtained in this study together with existing knowledge of Pd-catalyzed cross-coupling reactions are in agreement with the mechanism shown in Scheme 13, in which ligand dissociation plays a pivotal role in most of the steps. During pre-catalyst activation (Ac), phosphine dissociation is required to allow the transmetalation process that leads to monoligated $\mathrm{Pd}(0)$ after reductive elimination of haloborane. This $\mathrm{Pd}(0)$ species can either be stabilized with $\mathrm{PPh} / \mathrm{P}(\mathrm{o}-\mathrm{Tol})_{3}(\mathrm{a})$, or react either with $\mathrm{R}-\mathrm{X}(\mathrm{OA})$ or with unreacted pre-catalyst (b). The latter is potentially the first step in a route yielding trimetallic $\mathrm{Pd}$ species $\mathbf{1 1}$, which can be seen as a reservoir of $\mathrm{Pd}(0)$, as well as a source of $\left[\mathrm{PPh}_{4}\right] \mathrm{ZnX} \mathrm{X}_{3}$ and trans-[PdL $\left.2 \mathrm{PhX}\right]$ (which can enter into the catalytic cycle (c)) via P-Ph bond activation. In addition to catalyst activation, oxidative addition of R-X (OA) has 
been proposed in the literature to occur by mono-ligated Pd species, even in the case of $\mathrm{PPh}_{3}$ co-ligands..$^{40,44}$ The

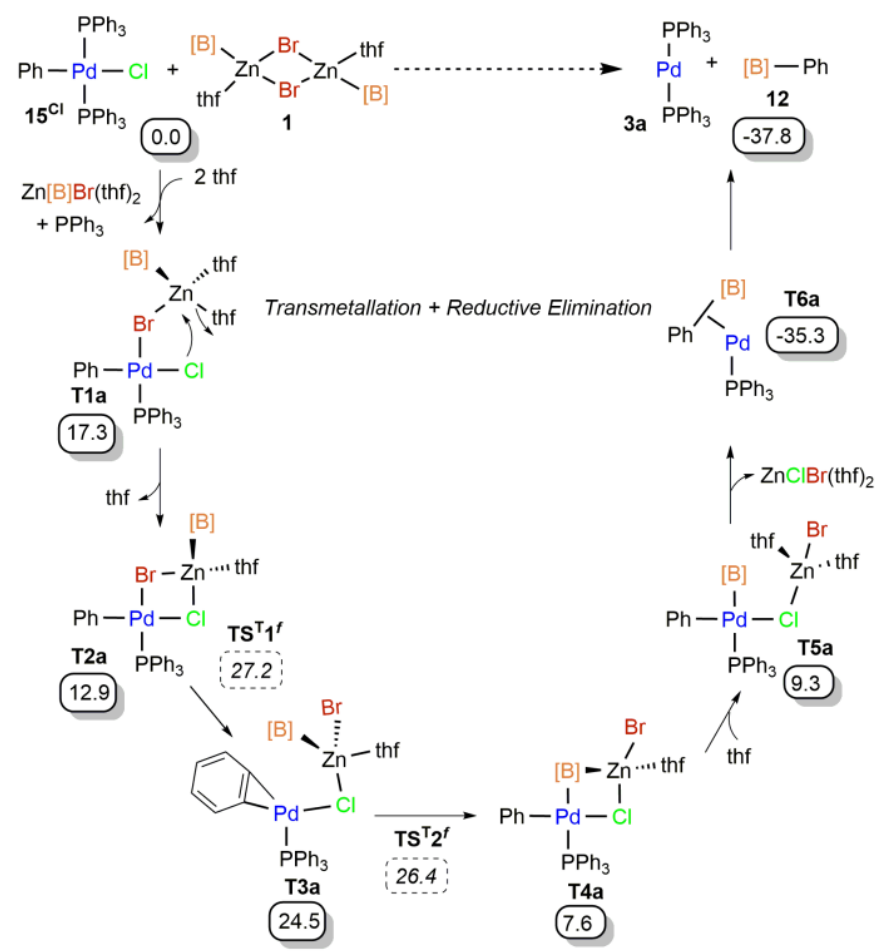

Scheme 12. Mechanism for the transmetalation pathway from E3 with the free energies $\left(\mathrm{kcal} \mathrm{mol}^{-1}\right)$ obtained for intermediates. The energies for $\mathbf{T S}^{\top} \mathbf{1}^{f}$ and $\mathbf{T S}^{\top} \mathbf{2}^{f}$ have been estimated by means of relaxed energy scan calculations (see SI).

electronically unsaturated and sterically unhindered $[\mathrm{PdLRX}]$ intermediates facilitate cis-trans isomerization, leading (reversibly) to trans-[PdL $\left.{ }_{2} \mathrm{RX}\right](\mathbf{9 a}, \mathbf{1 4 a})$ after phosphine re-combination - species that are experimentally observed during catalysis. Additionally, three-coordinate Pd compounds favor $\mathrm{CO}$ elimination (Elim), which is evidenced during the borylation of benzoyl chloride, particularly with the $\mathrm{PPh}_{3}$ system. Transmetalation (Tr) from such three-coordinate Pd species seems to be the rate-limiting step, yielding boryl Pd(II) intermediates. This is followed by reductive elimination (RE), which is expected to be almost barrierless and highly exoergic, consistent with the non-observation of any $\mathrm{Pd}-[\mathrm{B}]$ intermediates 


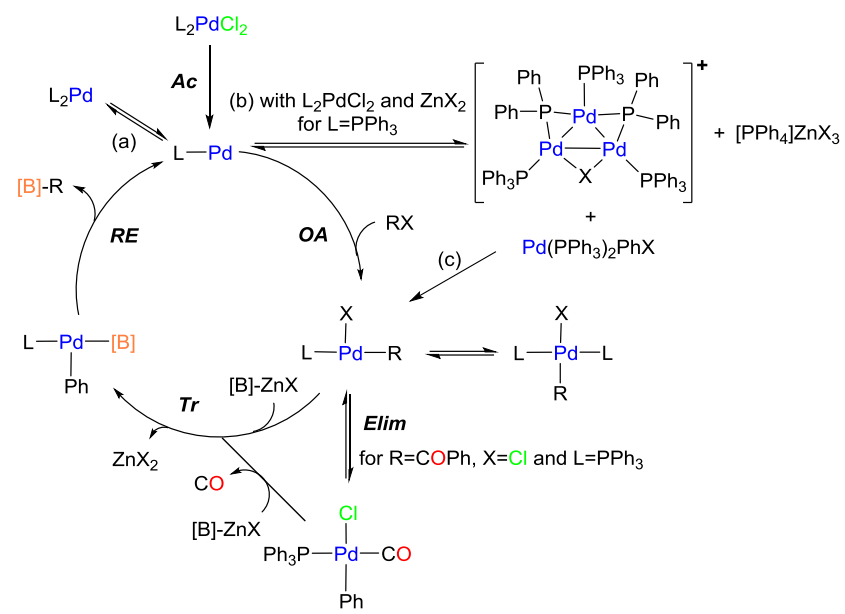

Scheme 13. Proposed catalytic cycle for the borylation of aryl bromides and acyl chlorides using borylzinc reagents and $\mathrm{L}_{2} \mathrm{PdCl}_{2}$ pre-catalysts.

Finally, taking into consideration the crucial role of mono-ligated formulation of palladium during most steps of the catalytic cycle we decided to examine the reactivity of related palladium complexes bearing a single $\mathrm{PPh}_{3}$ co-ligand. We focused on systems containing bulky $\eta^{3}$-indenyl ligands, which have recently been highlighted as convenient scaffolds that use steric factors to avoid the formation of inactive $\mathrm{Pd}(\mathrm{I})$ dimers. ${ }^{45}$ We therefore synthesized complexes $\left[\left(\eta^{3}\right.\right.$-indenyl) $\left.\mathrm{Pd}\left(\mathrm{PPh}_{3}\right) \mathrm{Cl}\right](\mathbf{1 7})$ and $\left[\left(\eta^{3}-1-^{t} \mathrm{Bu}\right.\right.$-indenyl) $\left.\mathrm{Pd}\left(\mathrm{PPh}_{3}\right) \mathrm{Cl}\right](\mathbf{1 8})$ from the reaction of $\mathrm{PPh}_{3}$ with dimeric $\left[\left(\eta^{3} \text {-indenyl }\right)_{2} \mathrm{Pd}_{2} \mathrm{Cl}_{2}\right]$ and $\left[\left(\eta^{3}-1-{ }^{t} \mathrm{Bu} \text {-indenyl }\right)_{2} \mathrm{Pd}_{2} \mathrm{Cl}_{2}\right]$, respectively (see Experimental Section for details). The catalytic performance of $\mathbf{1 7}$ and $\mathbf{1 8}$ in the borylation of bromobenzene by $\mathbf{1}$ under our standard conditions was then monitored by ${ }^{1} \mathrm{H}$ and ${ }^{11} \mathrm{~B}\left\{{ }^{1} \mathrm{H}\right\}$ NMR spectroscopy (Figure 6 ). As expected, the initial activity increases in the order $\mathbf{2 a}<\mathbf{1 7}<\mathbf{1 8}$. The initial induction period evident in the case of $\mathbf{2 a}$ is consistent with that shown in Figure 2 and is therefore ascribed to pre-catalyst activation/formation of $\left[\mathrm{Pd}(0)\left(\mathrm{PPh}_{3}\right)_{2}\right](3 a)$. The required phosphine dissociation is circumvented in the monoligated complexes $\mathbf{1 7}$ and $\mathbf{1 8}$ that apparently do not exhibit any significant induction periods. However, the indenyl pre-catalysts seem to decompose at 3\% catalyst loadings without reaching reaction completion and are surpassed by the simpler and affordable $\mathbf{2 a}$, pointing to the successful stabilization of resting states of catalyst by the second phosphine ligand. Lowering the temperature to $50 \stackrel{\circ}{\circ}$ brings about improved yields for bromobenzene borylation up to $85 \%$ using indenyl catalysts 17 and 18 , while carrying out these reactions at $25 \circ \mathrm{O}$ clearly demonstrates the superiority of the monoligated species under milder conditions (Figure 6). Further catalyst design optimization to balance the trade-off between activity and stability are currently being investigated in our group and will be reported in due course. 

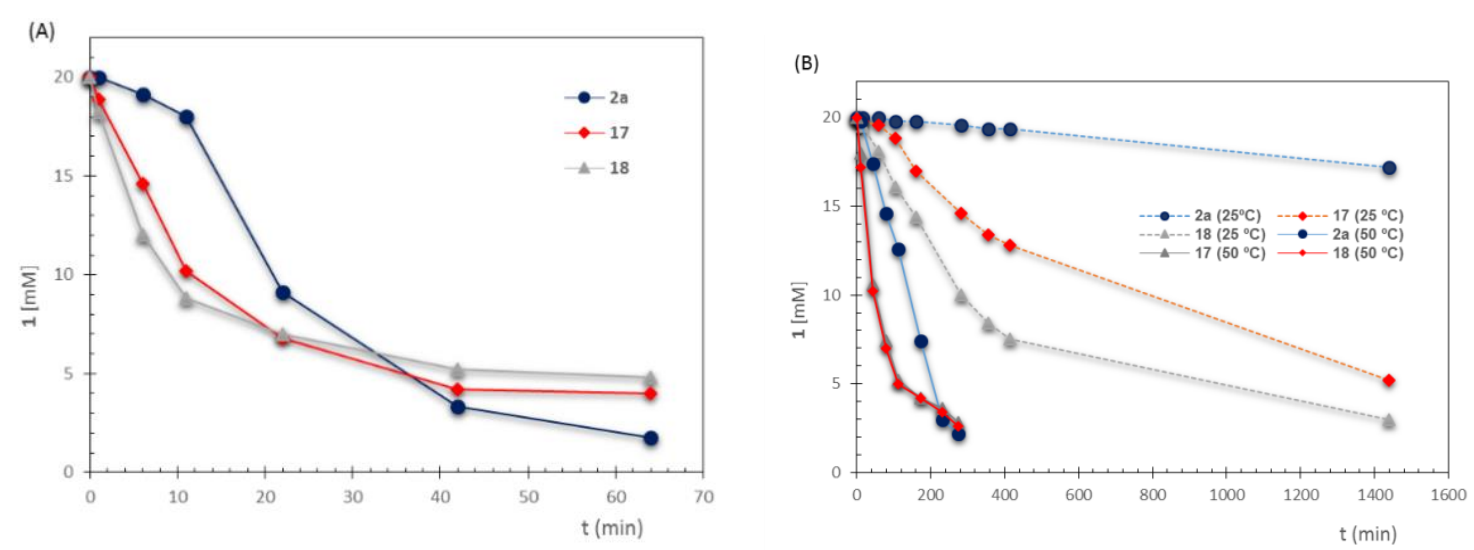

Figure 6. Reaction profile for the borylation of bromobenzene using $\mathbf{1}$ catalyzed by $\mathbf{2 a}$ (blue circle), $\mathbf{1 7}$ (red diamond) and 18 (grey triangle) at 80 (A), 50 (B) or 25 ㄷ (B). Reaction conditions: 1 (0.010 mmol), bromobenzene (0.022 mmol), [Pd] (3 mol\%), 1,4-dioxane (0.5 mL). Reaction monitoring by ${ }^{1} \mathrm{H} \mathrm{NMR}$ spectroscopy using an internal standard. Lines drawn to guide the eye.

\section{Conclusions}

In summary, we propose a complete mechanistic scheme (Scheme 13) for a recently developed bora-Negishi reaction, that allows the $\mathrm{Pd}$-catalyzed borylation of a variety of organic substrates. Importantly, it is the only method available for the systematic and catalytic preparation of acylboranes, which represent an unusual class of organoborane reagents of great potential in synthetic organic chemistry..$^{46}$ Experimentally, we have analyzed the mechanism by which the $\mathrm{Pd}(\mathrm{II})$ pre-catalyst is activated, isolated reaction intermediates and screened their catalytic competence, demonstrated the pivotal role of ligand dissociation and synthesized and tested alternative monoligated systems. These studies have been complemented by theo-retical investigations to obtain additional insight into each step of the catalytic cycle, as well as to learn about the causes for the divergent activity observed for related systems based on $\mathrm{PPh}_{3}$ and $\mathrm{P}(0-\mathrm{Tol})_{3}$ during the borylation of aryl bromides. This joint experimental/computational effort has thus provided key mechanistic information that we believe will pave the way toward future catalyst developments for improved activity/selectivity, and broader scope. These avenues and others are currently being pursued in our laboratories.

\section{Experimental Section}

General methods and instrumentation. All manipulations were carried out using standard Schlenk line or drybox techniques under an atmosphere of argon. Solvents were degassed with dinitrogen and dried by passing through a column of the appropriate drying agent. ${ }^{47} \mathrm{THF}$ was refluxed over sodium/benzophenone and distilled. NMR spectra were measured in benzene- $d_{6}$ (dried over sodium or potassium and distilled under reduced pressure) or $\mathrm{CDCl}_{3}$ (used as received). NMR samples were prepared under argon in $5 \mathrm{~mm}$ Wilmad 507-PP tubes fitted with J. Young Teflon valves. ${ }^{1} \mathrm{H},{ }^{13} \mathrm{C}\left\{{ }^{1} \mathrm{H}\right\},{ }^{11} \mathrm{~B}\left\{{ }^{1} \mathrm{H}\right\}$ and ${ }^{19} \mathrm{~F}\{1 \mathrm{H}\}$ NMR spectra were recorded on a Varian Mercury-VX-300, a Bruker Mercury Avance III HD NanoBay 400 or a Bruker Avance III 500 spectrometer at ambient temperature, and referenced internally to residual protio-solvent $\left({ }^{1} \mathrm{H}\right)$ or solvent $\left({ }^{13} \mathrm{C}\right)$ resonances, and are reported in ppm relative to tetramethylsilane $(\delta=0 \mathrm{ppm})$. Assignments were confirmed using two 
dimensional HSQC and HMBC correlation experiments. Carbon signals exhibiting significant line broadening due to quadrupolar relaxation caused by the proximity of boron atoms were not reported. Chemical shifts are quoted in ppm. Solid state and solution phase infrared spectra were measured on a Nicolet iS5 FT-IR spectrometer using air sealed $\mathrm{KBr}$-discs or $\mathrm{NaCl}$-cells. Elemental analyses were carried out at London Metropolitan University.

Starting materials. Borylzinc reagent $\mathbf{1}^{6}$ and palladium complexes $9 a,{ }^{48} 7,{ }^{29} \mathbf{8}^{29}{ }^{29} \mathbf{1 4} \mathrm{a}^{49}$ and $\mathbf{1} \mathbf{7}^{50}$ were synthesized according to literature procedures. Other palladium precursors and organic substrates were obtained from commercial sources and used as received.

$\mathrm{Zn}\left\{\mathrm{B}(\mathrm{NDippCH})_{2}\right\}_{2}$ (19). In a glove box, metallic potassium (367 mg, $9.42 \mathrm{mmol}$ ) was cleaned to remove oxide coating and finely suspended by vigorous stirring in $20 \mathrm{~mL}$ of refluxing absolute $n$-hexane under an argon atmosphere. A mixture of $\mathrm{ZnCl}_{2}(582 \mathrm{mg}, 4.28 \mathrm{mmol})$ and bromoborane $\left(\mathrm{Br}\left\{\mathrm{B}(\mathrm{NDippCH})_{2}\right\}, 20\right)(1000 \mathrm{mg}, 2.14$ $\mathrm{mmol}$ ) was prepared in a glove box and removed in sealed glass vial. The mixture was then added to the suspension of potassium sand at room temperature under a flow of argon. The reaction mixture was vigorously stirred for $24 \mathrm{~h}$ to form a dark grey suspension, filtered and dried in vacuo. NMR analysis of the crude residue showed full conversion of $\mathbf{2 0}$ to $47 \%$ of 19 and $53 \%$ of hydroborane $(\mathrm{H}\{\mathrm{B}(\mathrm{NDippCH}) 2\}) \mathbf{2 1}$. This mixture was dissolved in $9 \mathrm{~mL}$ of refluxing absolute $\mathrm{n}$-pentane, cooled to room temperature and kept in a $-26^{\circ} \mathrm{C}$ freezer for $48 \mathrm{~h}$. Large colorless crystals of $\mathbf{1 9}$ formed at this point which separated by filtration, washed with $0.5 \mathrm{~mL}$ of absolute $n$-pentane and dried in vacuo. Yield: $280 \mathrm{mg}, 31 \%$. Analytical data is identical to that reported previously. ${ }^{5 a}$

$\left[\left(\mathrm{Ph}_{3} \mathrm{P}\right)_{3} \mathrm{Pd}_{3}\left(\mu-\mathrm{PPh}_{2}\right)_{2}(\mu-\mathrm{Br})\right]^{+}(\mathbf{1 1})$. A mixture of palladium precursor $\mathbf{2 a}(50 \mathrm{mg}, 0.071 \mathrm{mmol})$ and borylzinc

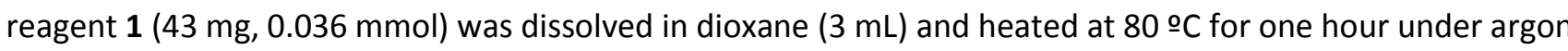
atmosphere. The resulting dark red solution was filtered, concentrated and compound $\mathbf{1 1}$ was obtained after precipitation with pentane as a bright orange solid 11 (17 mg, 40\%, assuming $\mathrm{ZnBrCl}_{2}{ }^{-}$as the counteranion on the basis of elemental analysis). Crystals suitable for $\mathrm{X}$-Ray diffraction analysis were grown by layering the dioxane solution with pentane and cooling the mixture at $-23 \stackrel{\circ}{\circ} \mathrm{C}$ overnight. ${ }^{1} \mathrm{H} \mathrm{NMR}\left(\mathrm{CD}_{2} \mathrm{Cl}_{2}, 400 \mathrm{MHz}\right): \delta 7.41(6$ $\mathrm{H}, \mathrm{t}), 7.37(4 \mathrm{H}, \mathrm{t}), 7.20(12 \mathrm{H}, \mathrm{t}), 7.13(3 \mathrm{H}, \mathrm{t}), 7.09(20 \mathrm{H}, \mathrm{m}), 6.80(6 \mathrm{H}, \mathrm{t}), 6.75(8 \mathrm{H}, \mathrm{m}), 6.59(6 \mathrm{H}, \mathrm{m})$. All aromatic ${ }^{3} J_{H H}$ have values of around $7.5 \mathrm{~Hz} .{ }^{13} \mathrm{C}\left\{{ }^{1} \mathrm{H}\right\} \mathrm{NMR}\left(\mathrm{CD}_{2} \mathrm{Cl}_{2}, 100 \mathrm{MHz}\right): \delta 135.1\left(\mathrm{vt}, \mathrm{J}_{\mathrm{CP}}=13 \mathrm{~Hz}, \mathrm{C}_{\mathrm{ipso}}\right), 134.0$ $\left(\mathrm{t}, \mathrm{J}_{\mathrm{CP}}=6 \mathrm{~Hz}, \mathrm{CH}\right), 133.0\left(\mathrm{~d}, \mathrm{~J}_{\mathrm{CP}}=13 \mathrm{~Hz}, \mathrm{CH}\right), 132.8\left(\mathrm{t}, \mathrm{J}_{\mathrm{CP}}=8 \mathrm{~Hz}, \mathrm{CH}\right), 132.5$ (d, J $\left.\mathrm{J}_{\mathrm{CP}}=22 \mathrm{~Hz}, \mathrm{C}_{\mathrm{ipso}}\right), 131.5$ (d, J JP $=41$ $\left.\mathrm{Hz}, \mathrm{C}_{\text {ipso }}\right), 130.5$ (d, J JP $\left.=13 \mathrm{~Hz}, \mathrm{CH}\right), 129.9$ (d, J $\mathrm{JP}_{C P}=3 \mathrm{~Hz}$ ), $128.3\left(\mathrm{t}, \mathrm{J}_{\mathrm{CP}}=5 \mathrm{~Hz}, \mathrm{CH}\right), 128.2\left(\mathrm{t}, \mathrm{J}_{\mathrm{CP}}=5 \mathrm{~Hz}, \mathrm{CH}\right), 127.9$ (d, $\left.\mathrm{J}_{\mathrm{CP}}=10 \mathrm{~Hz}, \mathrm{CH}\right) .{ }^{31} \mathrm{P}\left\{{ }^{1} \mathrm{H}\right\} \mathrm{NMR}\left(\mathrm{CD}_{2} \mathrm{Cl}_{2}, 162 \mathrm{MHz}\right)$ : ABB'XX' spin system $\left(\mathrm{J}_{\mathrm{AX}}=11, \mathrm{~J}_{\mathrm{AB}}=91 \mathrm{~Hz}\right), \delta 226.5\left(2 \mathrm{P}, \mathrm{m}, \mathrm{PPh}_{2}\right.$ (PX)), 19.0 (2 P, m, PPh $(\mathrm{PB})$ ), 12.3 (1 P, m, PPh $(\mathrm{PA})$ ). Elemental analysis found: $\mathrm{C}$ 52.33, H 3.47 \%, calculated for $\mathrm{C}_{78} \mathrm{H}_{65} \mathrm{Br}_{2} \mathrm{Cl}_{2} \mathrm{P}_{5} \mathrm{Pd}_{3} \mathrm{Zn} \mathrm{C} 52.85, \mathrm{H} 3.70 \%$. Crystallographic data: $\mathrm{C}_{156} \mathrm{H}_{130} \mathrm{Br}_{1.92} \mathrm{Cl}_{15.08} \mathrm{P}_{10} \mathrm{Pd}_{6} \mathrm{Zn}_{6}, \mathrm{Mr}=4032.93$, monoclinic, P21/n, $a=29.2833$ (3), $b=19.5660$ (2), $c=33.5346$ (5) $\AA, \beta=96.388(1)^{\circ}, V=19094.6(4) \AA^{3}, Z=4$, $\rho c=1.403 \mathrm{~g} \mathrm{~cm}^{-3}, T=150 \mathrm{~K}, \lambda=0.71073 \AA$. 78158 reflections collected, 36679 independent $[R($ int $)=0.072]$, which were used in all calculations. $R 1=0.1113$, wR2 $=0.2427$ for observed unique reflections $[I>2 \sigma(I)]$ and $R 1$ $=0.0884, w R 2=0.2308$ for all unique reflections. Max. and min. residual electron densities 4.00 and -1.75 e $\AA^{-3}$.

$\mathrm{Pd}(\mathrm{DPPBz}) \mathrm{PhBr}$ (15) (DPPBz = 1,2-bis(diphenylphosphino)benzene). 9a (250 mg, $0.318 \mathrm{mmol}$ ) and DPPBz (284 $\mathrm{mg}, 0.636 \mathrm{mmol}$ ) were suspended in benzene $(8 \mathrm{~mL})$ and the reaction mixture stirred at room temperature for 16 hours under $\mathrm{N}_{2}$ atmosphere. Pentane was added to complete precipitation, and the product was isolated 
after filtration and several washings with pentane giving a yellow powder (184 mg, 82\%). Spectroscopic details were identical to those previously reported for the same compound synthesized by an alternative method. ${ }^{51}$

$\mathrm{Pd}(\mathrm{DPPBz})(\mathrm{C}(\mathrm{O}) \mathrm{Ph}) \mathrm{Cl}$ (16) (DPPBz = 1,2-bis(diphenylphosphino)benzene). 14a (150 mg, $0.194 \mathrm{mmol}$ ) and DPPBz (172 $\mathrm{mg}, 0.389 \mathrm{mmol}$ ) were suspended in benzene $(5 \mathrm{~mL}$ ) and the reaction mixture stirred at room temperature for 16 hours under $\mathrm{N}_{2}$ atmosphere. Pentane was added to complete precipitation, and the product was isolated after filtration and several washings with pentane giving a yellow powder $(103 \mathrm{mg}, 77 \%) .{ }^{1} \mathrm{H} \mathrm{NMR}\left(\mathrm{CD}_{2} \mathrm{Cl}_{2}, 400\right.$ $\mathrm{MHz}): \delta 7.03-7.59(29 \mathrm{H}, \mathrm{m}) .{ }^{13} \mathrm{C}\left\{{ }^{1} \mathrm{H}\right\} \mathrm{NMR}\left(\mathrm{CD}_{2} \mathrm{Cl}, 100 \mathrm{MHz}\right): \delta 134.3,133.6\left(\mathrm{~d},{ }^{2} \mathrm{~J}_{\mathrm{CP}}=13 \mathrm{~Hz}\right), 133.3,132.1$, $131.7,131.0,130.6,130.3,129.7,128.9\left(\mathrm{~d},{ }^{2} \mathrm{~J}_{\mathrm{CP}}=10 \mathrm{~Hz}\right.$ ), $128.6\left(\mathrm{~d},{ }^{2} \mathrm{~J}_{\mathrm{CP}}=11 \mathrm{~Hz}\right), 128.3,127.7$ (signals due to quaternary carbon atoms were not observed). ${ }^{31} \mathrm{P}\left\{{ }^{1} \mathrm{H}\right\} \mathrm{NMR}\left(\mathrm{CD}_{2} \mathrm{Cl}_{2}, 162 \mathrm{MHz}\right): \delta 39.8\left(\mathrm{~d},{ }^{2} \mathrm{JPP}=42 \mathrm{~Hz}\right), 32.1(\mathrm{~d}$, $\left.{ }^{2} J_{\mathrm{PP}}=42 \mathrm{~Hz}\right) \cdot \mathrm{IR}\left(\mathrm{CH}_{2} \mathrm{Cl}_{2}\right): \mathrm{v}(\mathrm{CO}) 1590 \mathrm{~cm}^{-1}$. Elemental analysis found: $\mathrm{C} 63.93, \mathrm{H} 4.16 \%$, calculated for $\mathrm{C}_{37} \mathrm{H}_{29} \mathrm{ClOP}_{2} \mathrm{Pd} \mathrm{C} 64.09, \mathrm{H} 4.22 \%$.

$\left(\eta^{3}-1{ }^{t} \mathrm{Bu}\right.$-indenyl) $\mathrm{Pd}\left(\mathrm{PPh}_{3}\right) \mathrm{Cl}(\mathbf{1 8})$. Dimer $\left(\eta^{3} \text {-indenyl }\right)_{2}\left(\mu-\mathrm{Cl}_{2}\right)_{2} \mathrm{Pd}_{2}(80 \mathrm{mg}, 0.130 \mathrm{mmol})$, prepared from a reported procedure, ${ }^{45}$ and $\mathrm{PPh}_{3}(68 \mathrm{mg}, 0.260 \mathrm{mmol})$ were placed in a Schlenk flask and suspended in $\mathrm{Et}_{2} \mathrm{O}(8 \mathrm{~mL})$ under argon atmosphere. The suspension was stirred for two hours at room temperature, during which time the reaction mixture became homogeneous. The solution was filtered, concentrated and cooled to $-23 \circ \mathrm{C}$ overnight. Compound 18 was isolated as a brown crystalline powder $(106 \mathrm{mg})$ in $71 \%$ yield. ${ }^{1} \mathrm{H} \mathrm{NMR}\left(\mathrm{CD}_{2} \mathrm{Cl}_{2}, 400 \mathrm{MHz}\right): \delta$ $7.60-7.44\left(15 \mathrm{H}, \mathrm{m}, \mathrm{PPh}_{3}\right), 7.59\left(1 \mathrm{H}\right.$, obscured with $\mathrm{PPh}_{3}$ singals, Ind), $7.15\left(1 \mathrm{H}, \mathrm{t},{ }^{3} \mathrm{HHH}_{\mathrm{HH}}=7.4 \mathrm{~Hz}, \mathrm{Ind}\right), 6.93(1 \mathrm{H}$, $\mathrm{t},{ }^{3} \mathrm{H}_{\mathrm{HH}}=7.4 \mathrm{~Hz}$, Ind), $6.64\left(1 \mathrm{H}, \mathrm{d},{ }^{3} \mathrm{~J}_{\mathrm{HH}}=2.2 \mathrm{~Hz}\right.$, Ind), $6.35\left(1 \mathrm{H}, \mathrm{d},{ }^{3} J_{\mathrm{HH}}=7.4 \mathrm{~Hz}\right.$, Ind), $4.33\left(1 \mathrm{H}, \mathrm{t},{ }^{3} \mathrm{~J}_{\mathrm{HH}}=2.2 \mathrm{~Hz}\right.$, Ind), $1.65\left(9 \mathrm{H}, \mathrm{s},{ }^{t} \mathrm{Bu}\right) .{ }^{13} \mathrm{C}\left\{{ }^{1} \mathrm{H}\right\} \mathrm{NMR}\left(\mathrm{CD}_{2} \mathrm{Cl}_{2}, 100 \mathrm{MHz}\right): \delta 137.2$ (d, ${ }^{2} J_{\mathrm{CP}}=2 \mathrm{~Hz}$, Ind), 136.3 (d, ${ }^{2} J_{\mathrm{CP}}=5 \mathrm{~Hz}$, Ind), 134.0 (d, $\left.{ }^{2} J_{C P}=12 \mathrm{~Hz}, \mathrm{PPh}_{3}\right), 132.1\left(\mathrm{~d},{ }^{1} \mathrm{~J}_{\mathrm{CP}}=45 \mathrm{~Hz}, \mathrm{PPh}_{3}\right), 130.8$ (Ind), $130.6\left(\mathrm{~d},{ }^{4} \mathrm{~J}_{\mathrm{CP}}=3 \mathrm{~Hz}, \mathrm{PPh}_{3}\right), 128.4\left(\mathrm{~d},{ }^{3} \mathrm{JPP}_{\mathrm{CP}}=11 \mathrm{~Hz}\right.$, $\left.\mathrm{PPh}_{3}\right), 126.2,125.8,120.4,116.8$ (Ind), 107.9 (d, ${ }^{2} \mathrm{JPP}_{\mathrm{CP}}=7 \mathrm{~Hz}$, Ind), 73.5 (d, ${ }^{2} J_{\mathrm{CP}}=4 \mathrm{~Hz}$, Ind), 34.7 (d, ${ }^{3} \mathrm{~J}_{\mathrm{CP}}=5 \mathrm{~Hz}$, $\left.\mathrm{C}\left(\mathrm{CH}_{3}\right)\right), 29.5\left(\mathrm{~d},{ }^{4} \mathrm{~J}_{\mathrm{CP}}=5 \mathrm{~Hz}, \mathrm{C}\left(\mathrm{CH}_{3}\right)\right) \cdot{ }^{31} \mathrm{P}\left\{{ }^{1} \mathrm{H}\right\} \mathrm{NMR}\left(\mathrm{CD}_{2} \mathrm{Cl}_{2}, 162 \mathrm{MHz}\right): \delta 28.9$. Elemental analysis found: $\mathrm{C} 64.80, \mathrm{H}$ $5.12 \%$, calculated for $\mathrm{C}_{31} \mathrm{H}_{31} \mathrm{ClPPd} \mathrm{C} 64.59$, $\mathrm{H} 5.42 \%$.

Pre-activation experiments for trappig Pd(0) species. Two set of experiments were carried out: (A) $2 a$ (8 $\mathrm{mg}$, $0.011 \mathrm{mmol}$ ), borylzinc reagent 1 (16 mg, 2.5 equiv) and dvds ( $25 \mu \mathrm{L}, 10$ equiv) were placed in a Young's NMR tube inside a dry box and dissolved in dioxane $(0.6 \mathrm{~mL})$. The tube was heated at $80^{\circ} \mathrm{C}$ and conversion was monitored by ${ }^{31} \mathrm{P}\left\{{ }^{1} \mathrm{H}\right\}$ analysis; (b) 2a $(8 \mathrm{mg}, 0.011 \mathrm{mmol})$ and borylzinc reagent 1 (66 mg, 10 equiv) were placed in a Young's NMR tube inside a dry box and dissolved in dioxane $(0.6 \mathrm{~mL})$. The tube was heated at $80^{\circ} \mathrm{C}$ for 30 min and then dvds ( $12 \mu \mathrm{L}, 5$ equiv) or bromobenzene ( $6 \mu \mathrm{L}, 5$ equiv) were added inside a dry box. Conversion was monitored by ${ }^{31} \mathrm{P}\left\{{ }^{1} \mathrm{H}\right\}$ analysis.

Pre-activation experiments with variable amounts of 1. 2a (10 mg, $0.014 \mathrm{mmol})$ and variable amounts of borylzinc reagent 1 ( 0.5 to 10 equiv) were placed in a Young's NMR tube inside a dry box and dissolved in dioxane $(0.6 \mathrm{~mL})$. The tube was heated at $80{ }^{\circ} \mathrm{C}$ for $30 \mathrm{~min}$. Conversion and selectivity data were obtained by ${ }^{1} \mathrm{H}$ and ${ }^{31} \mathrm{P}\{1 \mathrm{H}\}$ NMR analysis of the crude mixtures using a capillary charged with trimethoxybenzene and $\mathrm{P}(\mathrm{OPh})_{3}$ as internal standards.

General procedure for catalytic borylation. In a typical experiment borylzinc reagent 1 (12 $\mathrm{mg}, 0.010 \mathrm{mmol})$ was placed in a Young's NMR tube inside a dry box, and the corresponding organic substrate (bromobenzene or benzoyl chloride, $0.022 \mathrm{mmol}, 1.1$ equiv) then added. Palladium pre-catalyst was transferred into the mixture as a stock solution in dry 1,4-dioxane or thf $(0.5 \mathrm{~mL}, 5 \mathrm{~mol} \%)$ and the tube heated at $80^{\circ} \mathrm{C}$ for up to $2 \mathrm{~h}$, time 
during which ${ }^{1} \mathrm{H}$ NMR data were obtained using trimethoxybenzene as an internal standard to build the corresponding reaction profiles.

Stoichiometric experiments between 1 and Pd compounds. Borylzinc reagent 1 (12 $\mathrm{mg}, 0.010 \mathrm{mmol}$ ) and the corresponding palladium compound (9a, $16 \mathrm{mg}, 0.020 \mathrm{mmol}$; 14a, $15 \mathrm{mg}, 0.020 \mathrm{mmol}$; 15, $14 \mathrm{mg}, 0.020 \mathrm{mmol}$; $16,14 \mathrm{mg}, 0.020 \mathrm{mmol}$ ) were placed in a Young's NMR tube inside a dry box and dissolved in thf- $d_{8}$ or dioxane $(0.6 \mathrm{~mL})$. The tube was heated at $80{ }^{\circ} \mathrm{C}$ for $3 \mathrm{~h}$. Conversion and selectivity data were obtained by ${ }^{1} \mathrm{H}$ and ${ }^{31} \mathrm{P}\{1 \mathrm{H}\}$ NMR analysis of the crude mixtures using a capillary charged with trimethoxybenzene and $\mathrm{P}(\mathrm{OPh})_{3}$ as internal standards.

Catalytic borylation of $\left[\mathrm{PPh}_{4}\right][\mathrm{X}]$. Borylzinc reagent $1(27 \mathrm{mg}, 0.022 \mathrm{mmol})$ and $\left[\mathrm{PPh}_{4}\right] \mathrm{Cl}(16 \mathrm{mg}, 0.044 \mathrm{mmol})$ were placed in a Young's NMR tube inside a dry box (in some experiments $\mathrm{ZnBr}_{2}$ (10 mg, 1equiv) was also added to form $\mathrm{ZnX}_{3}{ }^{-}$in situ). $\mathrm{Pd}\left(\mathrm{PPh}_{3}\right)_{2} \mathrm{Cl}_{2}$ was transferred into the mixture as a stock solution in dry dioxane $(0.5 \mathrm{~mL}$, $2.2 \mathrm{mM}, 5 \mathrm{~mol} \%$ ) and the tube heated at $80{ }^{\circ} \mathrm{C}$ for $2 \mathrm{~h}$. Conversion and selectivity data were obtained by ${ }^{1} \mathrm{H}$ NMR analysis of the crude mixture after addition of trimethoxybenzene as internal standard.

Computational details. Two different DFT functionals (M06L and M06) and basis sets (BS1 and BS2) were selected for geometry optimization and energy refinement, in order to optimize accuracy and computational cost. All stationary points were fully optimized with the pure MO6L functional ${ }^{52}$ including dispersion, as implemented in the Gaussian09 soft-ware package (Rev. D.01). ${ }^{53}$ Geometry optimizations were carried out on the full system including solvation by THF with the continuum SMD model. ${ }^{54}$ Frequencies were computed with the aim of classifying all stationary points as either minima or transition states and determining the thermochemistry corrections, ( $\mathrm{G}-\mathrm{E})$, which include the zero-point, thermal and entropy energies. BS1 was used for geometry optimizations and includes polarization functions and small-core pseudopotentials by combining the double- $\zeta 6-31 \mathrm{G}^{* *}(\mathrm{C}, \mathrm{N}, \mathrm{O} \text { and } \mathrm{H})^{55}$ and LANL2DZ $(\mathrm{Pd})^{56}$ basis sets. Single point calculation on the optimized structures was performed by using the hybrid M06 functional, including solvation and using the triple- $\zeta$ BS2, in which Pd was described with the LANL2TZ(f) basis set ${ }^{57}$ and $C, N O$ and $\mathrm{H}$ were described with the $6-311+G^{* *}$ basis set, ${ }^{58}$ including polarization and diffuse functions. The free energies discussed in the text were obtained by adding the thermochemistry corrections, (G - E), at the DFT(M06L)/SMD/BS1 level, to the potential energies refined at the DFT(M06)/SMD/BS2 level. These energies were corrected for a $1 \mathrm{M}$ standard state..

\section{Acknowledgements}

J.C. thanks the EU 7th Framework Program, Marie Skłodowska-Curie actions (COFUND, Grant Agreement no. 267226) and Junta de Andalucía for a Talentia Postdoc. E.K. thanks the EU 7th Framework Program, Marie Skłodowska-Curie actions (PIEF-GA-2013-626441). A.N. thanks the Norwegian Research Council through the grants (221801/F20 and 250044/F20), the Center of Excellence for Theoretical and Computational Chemistry (CTCC; grant No. 179568/V30) and the Norwegian Metacenter for Computational Science (NOTUR; grant nn4654k).

Keywords: borylation $\bullet$ cross-coupling $\bullet$ borylzinc $\bullet$ palladium $\bullet$ acylborane

[1] (a) Metal Catalyzed Cross-Coupling Reactions (Ed.: F. Diederich and P. J. Stang), Wiley-VCH, Weinheim, 2008; (b) I. A. I. Mkhalid, J. H. Barnard, T. B. Marder, J. M. Murphy, J. F. Hartwig, Chem. Rev., 2010, 110, 890; (c) 
S. L. Buchwald, Cross-Coupling (Guest Editorial). Acc. Chem. Res., 2008, 41, 1439; (d) P. G. Gildner and T. J. Colacot, Organometallics, 2015, 34, 5497.

[2] (a) K. C. Nicolaou, P. G. Bulger and D. Sarlah, Angew. Chem. Int. Ed., 2005, 44, 4442; (b) C. Torborg and M. Beller, Adv. Synth. Catal., 2009, 351, 3027; (c) T. W. J. Cooper, I. B. Campbell and S. J. F. Macdonald, Angew. Chem. Int. Ed. 2010, 49, 8082.

[3] A. J. J. Lennox and G. C. Lloyd-Jones, Chem. Soc. Rev., 2014, 43, 412.

[4] (a) W. K. Chow, O. Y. Yuen, P. Y. Choy, C. M. So, C. P. Lau, W. T. Wong and F. Y. Kwong, RSC Advances, 2013, 3, 12518; (b) Boronic Acids: Preparation and Applications in Organic Synthesis Medicine and Materials (Ed.: D. G. Hall), 2nd ed., Wiley-VCH, Weinheim, 2011

[5] T. Kajiwara, T. Terabayashi, M. Yamashita, and K. Nozaki, Angew. Chem. Int. Ed., 2008, 47, 6606.

[6] J. Campos and S. Aldridge Angew. Chem., Int. Ed., 2015, 54, 14159.

[7] (a) M. R. Ibrahim, M. Bîhl, R. Knab and P. V. R. Schleyer, J. Comput. Chem., 1992, 13, 423; (b) G. Schmid and H. Nçth, Chem. Ber., 1968, 101, 2502; (c) K. Smith and K. J. Swaminathan, Chem. Soc. Chem. Commun., 1975, 719; (d) K. Smith and K. J. Swaminathan, J. Chem. Soc. Dalton Trans. 1976, 2297.

[8] (a) Y. Segawa, Y. Suzuki, M. Yamashita and K. Nozaki, J. Am. Chem. Soc. 2008, 130, 16069; (b) M. Yamashita, Y. Suzuki, Y. Segawa and K. Nozaki, J. Am. Chem. Soc., 2007, 129, 9570.

[9] (a) J. Monot, A. Solovyev, H. Bonin-Dubarle, E. Derat, D. P. Curran, M. Robert, L. Fensterbank, M. Malacria and E. Lacüte, Angew. Chem. Int. Ed., 2010, 49, 9166; (b) W. E. Piers and T. Chivers, Chem. Soc. Rev., 1997, 26, 345; (c) M. Sajid, G. Kehr, C. G. Daniliuc and G. Erker, Angew. Chem. Int. Ed., 2014, 53, 1118.

[10] (a) G. A. Molander, J. Raushel and N. M. Ellis, J. Org. Chem., 2010, 75, 4304; (b) Z. He, A. Zajdlik, J. D. St. Denis, N. Assem and A. K. Yudin, J. Am. Chem. Soc., 2012, 134, 9926; (c) Z. He, P. Trinchera, S. Adachi, J. D. St Denis and A. K. Yudin, Angew. Chem. Int. Ed. 2012, 51, 11092; (d) A. M. Dumas and J. W. Bode, Org. Lett., 2012, 14, 2138; (e) H. Noda, G. Eros and J. W. Bode, J. Am. Chem. Soc., 2014, 136, 5611; (f) G. Eros, Y. Kushida, J. W. Bode, Angew. Chem. Int. Ed., 2014, 53, 7604; (g) H. Noda and J. W. Bode, Chem. Sci. 2014, 5, 4328; (h) H. Noda and J. W. Bode, J. Am. Chem. Soc. 2015, 137, 3958; (i) A. M. Dumas, G. A. Molander, G. A. and J. W. Bode, Angew. Chem. Int. Ed., 2012, 51, 5683.

[11] (a) M. García-Melchor, A. A. C. Braga, A. Lledós, G. Ujaque and F. Maseras, Acc. Chem. Res., 2013, 46, 2626; (b) L. Xue and Z. Lin, Chem. Soc. Rev., 2010, 39, 1692; (c) C. Amatore and A. Jutand, Acc. Chem. Res. 2000, 33, 314; (d) C. Amatore and A. Jutand, J. Organomet. Chem., 1999, 576, 254.

[12] (a) K. Bçck, J. E. Feil, K. Karaghiosoff and K. Koszinowski, Chem. Eur. J., 2015, 21, 5548; (b) T. D. Bluemke, W. Clegg, P. García-Alvarez, A. R. Kennedy, K. Koszinowski, M. D. McCall, L. Russo and E. Hevia, Chem. Sci., 2014, 5, 3552; (c) G. T. Achonduh, N. Hadei, C. Valente, S. Avola, C. J. O'Brien and M. Organ, Chem. Commun., 2010, 46, 4109; (d) R. Álvarez, A. R. de Lera, J. M. Aurrecoechea, A. Durana, Organometallics, 2007, 26, 2799; (e) B. Fuentes, M. García-Melchor, A. Lledós, F. Maseras, J. A. Casares, G. Ujaque and P. Espinet, Chem. Eur. J., 2010, 16, 8596; (f) A. González-Pérez, R. Álvarez, O. N. Faza, A. R. de Lera and J. M. Aurrecoechea, Organometallics, 2012, 31, 2053; (g) L. C. McCann and M. G. Organ, Angew. Chem. Int. Ed., 2014, 53, 4386; (h) C. Adamo, C. 
Amatore, I. Ciofini, A. Jutand and H. Lakmini, J. Am. Chem. Soc., 2006, 128, 6829; (i) J. del Pozo, E. Gioria, J. A. Casares, R. Álvarez and P. Espinet, Organometallics, 2015, 34, 3120; (j) H. Duan, L. Meng, D. Bao, H. Zhang, Y. Li and A. Lei, Angew. Chem. Int. Ed., 2010, 49, 6387; (k) E. Hevia and R. Mulvey, Angew. Chem. Int. Ed., 2011, 50, 6448; (I) M. García-Melchor, B. Fuentes, A. Lledós, J. A. Casares, G. Ujaque and P. Espinet, J. Am. Chem. Soc., 2011, 133, 13519; (m) J. del Pozo, M. Pérez-Iglesias, R. Álvarez, A. Lledós, J. A. Casares, P. Espinet, ACS Catal. 2017, 7, 3575

[13] (a) K. Takahashi, T. Ishiyama and N. Miyaura, Chem. Lett., 2000, 29, 982; (b) M. Gao, S. B. Thorpe, C. Kleeberg, C. Slebodnick, T. B. Marder, W. L. Santos, J. Org. Chem., 2011, 76, 3997; (c) L. Dang, Z. Lin, T. B. Marder, Chem. Commun., 2009, 3987; (d) H. Zhao, L. Dang, T. B. Marder, Z. Lin, J. Am. Chem. Soc., 2008, 130, 5586; (e) H. Zhao, Z. Lin and T. B. Marder, J. Am. Chem. Soc., 2006, 128, 15637; (f) A. Bonet, H. Guly, E. Fernández, Angew. Chem. Int. Ed., 2010, 49, 5130; (g) J. Cid, J. J. Carbó and E. Fernández, Chem. Eur. J., 2014, 20, 3616; (h) Y. Yamamoto, M. Takizawa, X. Q. Yu and N. Miyaura, Angew. Chem. Int. Ed., 2008, 47, 928; (i) C. Kleeberg, A. G. Crawford, A. S. Batsanov, P. Hodgkinson, D. C. Apperley, M. S. Cheung, Z. Lin and T. B. Marder, J. Org. Chem., 2012, 77, 785; (j) S. Pietsch, U. Paul, I. A. Cade, M. J. Ingleson, U. Radius and T. B. Marder, Chem. Eur. J., 2015, 21, 9018; (k) S. Pietsch, E. C. Neeve, D. C. Apperley, R. Bertermann, F. Mo, D. Qiu, M. S. Cheung, L. Dang, J. Wang, U. Radius, Z. Lin, C. Kleeberg and T. B. Marder, Chem. Eur. J., 2015, 21, 7082; (I) R. D. Dewhurst, E. C. Neeve, H. Braunschweig and T. B. Marder, Chem. Commun., 2015, 51, 9594.

[14] (a) K. C. Lam, T. B. Marder and Z. Lin, Organometallics, 2010, 29, 1849; (b) N. Miyaura, K. Yamada, H. Suginome and A. Suzuki, J. Am. Chem. Soc., 1985, 107, 972; (c) T. Ishiyama, M. Murata and N. Miyaura, J. Org. Chem., 1995, 60, 7508; (d) M. Sumimoto, N. Iwane, T. Takahama and S. Sakaki, J. Am. Chem. Soc., 2004, 126, 10457; (e) A. A. C. Braga, N. H. Morgon, G. Ujaque, A. Lledós and F. Maseras, J. Organomet. Chem., 2006, 691, 4459; (f) R. Glaser and N. Knotts, J. Phys. Chem. A, 2006, 110, 1295; (g) J. Jover, N. Fey, M. Purdie, G. C. LloydJones and J. N. Harvey, J. Mol. Catal. A, 2010, 324, 39.

[16] (a) Y. Segawa, M. Yamashita and K. Nozaki, Science, 2006, 314, 113; (b) T. B. Marder, Science, 2006, 314, 69; (c) H. Braunschweig, Angew. Chem. Int. Ed., 2007, 46, 1946.

[17] (a) A. Sundermann, O. Uzan and J. M. L. Martin, Chem. Eur. J., 2001, 7, 1703; (b) A. J. Canty, Acc. Chem. Res., 1992, 25, 83; (c) C. Amatore, M. Catellani, S. Deledda, A. Jutand and E. Motti, Organometallics, 2008, 27, 4549; (d) W. A. Herrmann, C. Brossmer, K. Ofele, C.-P. Reisinger, T. Priermeier, M. Beller and H. Fischer, Angew. Chem. Int. Ed., 1995, 34, 1844; (e) L.-M. Xu, B.-J. Li, Z. Yang and Z.-J. Shi, Chem. Soc. Rev., 2010, 39, 712; (f) Y. Ye, N. D. Ball, J. W. Kampf and M. S. Sanford, J. Am. Chem. Soc., 2010, 132, 14682; (g) A. J. Hickman and M. S. Sanford, Nature, 2012, 484, 177.

[18] (a) M. Pagliaro, V. Pandarus, R. Ciriminna, F. Boland, P. D. Car, ChemCatChem, 2012, 4, 432; (b) L. Yin and J. Liebscher, Chem. Rev., 2007, 107, 133; (c) M. Pérez-Lorenzo, J. Phys. Chem. Lett., 2012, 3, 167; (d) M. Mora, C. Jiménez-Sanchidrián and J. R. Ruiz, Curr. Org. Chem., 2012, 16, 1128; (e) D. Astruc, Inorg. Chem., 2007, 46, 1884.

[19] (a) R. H. Crabtree, Chem. Rev., 2012, 112, 1536; (b) J. A. Widegren and R. G. Finke, J. Mol. Catal. A, 2003, $198,317$. 
[20] (a) S. K. Bose, K. Fucke, L. Liu, P. G. Steel and T. B. Marder, Angew. Chem. Int. Ed., 2014, 53, 1799; (b) S. K. Bose and T. B. Marder, Org. Lett., 2014, 16, 4562; (c) S. K. Bose, A. Deißenberger, A. Eichhorn, P. G. Steel, Z. Lin and T. B. Marder, Angew. Chem. Int. Ed., 2015, 54, 11843.

[21] (a) C. Amatore, A. Jutand, M. A. M'Barki, Organometallics, 1992, 11, 3009; (b) F. Ozawa, A. Kubo and T. Hayashi, Chem. Lett., 1992, 2177; (c) C. Amatore, E. Carre, A. Jutand and M. A. M'Barki, Organometallics, 1995, 14, 1818.

[22] A. F. Shmidt and V. V. Smirnov, Kinet. Catal., 2002, 43, 195.

[23] (a) L. Malatesta and M. Angoletta, J. Chem. Soc., 1957, 1186; (b) M. Enders, G. Kohl and H. Pritzkow, Organometallics, 2002, 21, 1111; (c) S. Köchera, G. P. M. van Klinkb, G. van Koten and H. Langa, J. Organomet. Chem., 2003, 684, 230.

[24] (a) C. R. Coulson, Inorg. Synth., 1970, 13, 121; (b) E. Negishi, T. Takahashi and K. Akiyoshi, J. Chem. Soc., Chem. Commun., 1986, 1338; (c) J. Louie and J. F. Hartwig, Angew. Chem. Int. Ed., 1996, 35, 2359; (d) R. Benhaddou, S. Czernecki, G. Ville, A. Zegar, Organometallics, 1988, 7, 2435; (e) S. Fantasia and S. P. Nolan, Chem. Eur. J., 2008, 14, 6987; (f) D. P. Hruszkewycz, D. Balcells, L. M. Guard, N. Hazari and M. Tilset, J. Am. Chem. Soc., 2014, 136, 7300.

[25] C. Amatore, M. Azzabi and A. Jutand, J. Organomet. Chem., 1989, 363, C41.

[26] (a) M. A. Fredricks and M. Drees, ChemCatChem, 2010, 2, 1467; (b) M. Wakioka, M. Nagao and F. Ozawa, Organometallics, 2008, 27, 602; (c) S. Borjian and M. C. Baird, Organometallics, 2014, 33, 3936; (d) B. Marciniec and E. J. Mackowska, Mol. Catal., 1989, 51, 41; (e) Z. Bao, W. K. Chan and L. Yu, J. Am. Chem. Soc., $1995,117,12426$.

[27] R. Jackstell, S. Harkal, H. Jiao, A. Spannenberg, C. Borgmann, D. Röttger, F. Nierlich, M. Elliot, S. Niven, K. Cavell, O. Navarro, M. S. Viciu, S. P. Nolan and M. Beller, Chem. Eur. J., 2004, 10, 3891.

[28] J. Krause, G. Cestaric, K.-J. Haack, K. Seevogel, W. Storm and K.-R. Poerschke, J. Am. Chem. Soc., 1999, $121,9807$.

[29] (a) E. Amadio and L. Toniolo, J. Organomet. Chem., 2014, 767, 72; (b) A. Balázsa, C. Benedekb and S. Tőrös, J. Mol. Catal. A, 2006, 244, 105.

[30] (a) M. R. Mason and J. G. Verkade, Organometallics, 1992, 11, 2212; (b) D. S. McGuinness, N. Saendig, B. F. Yates and K. J. Cavell, J. Am. Chem. Soc., 2001, 123, 4029.

[31] (a) P. E. Garrou, Chem. Rev., 1985, 85, 171; (b) S. A. Macgregor, Chem. Soc. Rev., 2007, 36, 67; (c) A. W. Parkins, Coord. Chem. Rev., 2006, 250, 449.

R. H. Crabtree, Chem. Rev., 2015, 115, 127.

[33] The calculated energy barrier for the Ph-P reductive elimination from $9 \mathrm{a}$ is $25.3 \mathrm{kcal} \mathrm{mol}^{-1}$ (see Supporting Information). See also: (a) M. Wakioka, Y. Nakajima and F. Ozawa, Organometallics, 2009, 28, 2527. 
(b) T. Rünzi, U. Tritschler, P. Roesle, I. Göttker-Schnetmann, H. M. Möller, L. Caporaso, A. Poater, L. Cavallo, and S. Mecking, Organometallics, 2012, 31, 8388.

[34] (a) G. W. Bushnell, K. R. Dixon, P. M. Moroney, A. D. Rattray and C. Wan, J. Chem .Soc. Chem. Commun., 1977, 709; (b) D. W. Berry, G. W. Bushnell, K. R. Dixon, P. M. Moroney, A. D. Rattray and C. Wan, Inorg. Chem., 1985, 24, 2625; (c) K. R. Dixon and A. D. Rattray, Inorg. Chem, 1978, 17, 1978.

[35] (a) B. E. Segelstein, T. W. Butler, B. L. Chenard, J. Org. Chem., 1995, 60, 12. (b) J. F. Hartwig and F. Paul, J. Am. Chem. Soc. 1995, 117, 5373.

[36] K. J. Bonney and F. Schoenebeck, Chem. Soc. Rev., 2014, 43, 6609.

[37] (a) R. Frank, J. Howell, R. Tirfoin, D. Dange, C. Jones, D. M. P. Mingos and S. Aldridge, J. Am. Chem. Soc., 2014, 136, 15730; (b) Y. Segawa, Y. Suzuki, M. Yamashita and K. Nozaki, J. Am. Chem. Soc., 2008, 130, 16069.

[38] (a) E. R. Strieter, D. G. Blackmond and S. L. Buchwald, J. Am. Chem. Soc., 2003, 125, 13978; (b) U. Christmann and R. Vilar, Angew. Chem. Int. Ed., 2005, 44, 366.

[39] C. M. Fafard, D. Adhikari, B. M. Foxman, D. J. Mindiola and O. V. Ozerov, J. Am. Chem. Soc., 2007, 129, 10318.

[40] The energy barrier for this process in a related system has been computed to be $10 \mathrm{kcal} \mathrm{mol}^{-1}$. See: $\mathrm{K}$. Vikse, T. Naka, J. S. McIndoe, M. Besora and F. Maseras, ChemCatChem, 2013, 5, 3604.

[41] (a) A. J. J. Lennox and G. C. Lloyd-Jones, Angew. Chem. Int. Ed., 2013, 52, 7362; (b) D. V. Partyka, Chem. Rev., 2011, 111, 1529; (c) A. A. Thomas, S. E. Denmark, Science, 2016, 352, 329.

[42] (a) J. A. Casares, P. Espinet, B. Fuentes and G. Salas, J. Am. Chem. Soc. 2007, 129, 3508; (b) R. van Asselt, and C. J. Elsevier, Organometallics 1994, 13, 1972; (c) Q. Liu, Y. Lan, J. Liu, G. Li, Y. D. Wu and A. Lei, J. Am. Chem. Soc. 2009, 131, 10201.

[43] (a) V. V. Grushin, Organometallics, 2000, 19, 1888; (b) F. Paul, J. Patt and J. F. Hartwig, J. Am. Chem. Soc., 1994, 116, 5969.

[44] M. Ahlquist, P. Fristrup, D. Tanner and P.-O. Norrby, Organo-metallics, 2006, 25, 2066.

[45] P. R. Melvin, A. Nova, D. Balcells, W. Dai, N. Hazari, D. P. Hruszkewycz, H. P. Shah and M. T. Tudge, ACS Catal. 2015, 5, 3680.

[46] F. K. Scharnagl, S. K. Bose and T. B. Marder, Org. Biomol. Chem., 2017, 15, 1738.

[47] A. B. Pangborn, M. A. Giardello, R. H. Grubbs, R. K. Rosen, F. J. Timmers, Organometallics, 1996, 15, 1518.

[48] F. Ozawa, T. Sugimoto, Y. Yuasa, M. Santra, T. Yamamoto, A. Yamamoto, Organometallics, 1984, 3, 683.

[49] H. Kuniyasu, A. Sanagawa, D. Nakane, T. Iwasaki, N. Kambe, K. Bobuatong, Y. Lu and M. Ehara, Organometallics, 2013, 32, 2026. 
[50] C. Sui-Seng, G. D. Enright and D. Zargarian, Organometallics, 2004, 23, 1236.

[51] D. A. Culkin and J. F. Hartwig, Organometallics, 2004, 23, 3398.

[52] Y. Zhao and D. G. Truhlar, J. Chem. Phys., 2006, 125, 194101.

[53] Gaussian 09, Revision D.01, M. J. Frisch, G. W. Trucks, H. B. Schlegel, G. E. Scuseria, M. A. Robb, J. R. Cheeseman, G. Scalmani, V. Barone, B. Mennucci, G. A. Petersson, H. Nakatsuji, M. Caricato, X. Li, H. P. Hratchian, A. F. Izmaylov, J. Bloino, G. Zheng, J. L. Sonnenberg, M. Hada, M. Ehara, K. Toyota, R. Fukuda, J. Hasegawa, M. Ishida, T. Nakajima, Y. Honda, O. Kitao, H. Nakai, T. Vreven, J. A. Montgomery, Jr., J. E. Peralta, F. Ogliaro, M. Bearpark, J. J. Heyd, E. Brothers, K. N. Kudin, V. N. Staroverov, R. Kobayashi, J. Normand, K. Raghavachari, A. Rendell, J. C. Burant, S. S. Iyengar, J. Tomasi, M. Cossi, N. Rega, J. M. Millam, M. Klene, J. E. Knox, J. B. Cross, V. Bakken, C. Adamo, J. Jaramillo, R. Gomperts, R. E. Stratmann, O. Yazyev, A. J. Austin, R. Cammi, C. Pomelli, J. W. Ochterski, R. L. Martin, K. Morokuma, V. G. Zakrzewski, G. A. Voth, P. Salvador, J. J. Dannenberg, S. Dapprich, A. D. Daniels, O. Farkas, J. B. Foresman, J. V. Ortiz, J. Cioslowski, and D. J. Fox, Gaussian, Inc., Wallingford CT, 2009.

[54] A. V. Marenich, C. J. Cramer and D. G. Truhlar, J. Phys. Chem. B, 2009, 113, 6378.

[55] W. J. Hehre, R. Ditchfield and J. A. Pople, J. Chem. Phys., 1972, 56, 2257.

[56] P. J. Hay and W. R. Wadt, J. Chem. Phys., 1985, 82, 299.

[57] L. E. Roy, P. J. Hay and R. L. Martin, J. Chem. Theory Comput., 2008, 4, 1029.

[58] (a) A. D. McLean, G. S. Chandler, J. Chem. Phys., 1980, 72, 5639; (b) R. Krishnan, J. S. Binkley, R. Seeger and J. A. Pople, J. Chem. Phys., 1980, 72, 650. 
